\title{
OBICEIURILE FAMILIALE: IMPLICAȚII PENTRU STAREA DE BINE
}

\author{
Diana Georgiana Culea, Sebastian Pintea \\ Departamentul de Psihologie, Facultatea de Psihologie și Științe ale Educaţiei, \\ Universitatea Babeș-Bolyai, Cluj-Napoca
}

\section{Rezumat}

OBIECTIVE: Acest studiu are scopul de a investiga influența rutinelor și ritualurilor familiale asupra stării de bine a individului.

METODE: Metoda folosită a fost completarea unor scale online (Family Routines Inventory, Ryff Psychological Well-Being Scale), evaluarea frecvenței și semnificației afective ale anumitor obiceiuri din familia de origine, cât și a stării de bine din prezent a individului, și studierea relației dintre aceste variabile în cazul a 129 de subiecți cu vârste curprinse între 18 și 71 de ani, cu statut socio-economic crescut spre mediu, din mediul urban.

REZULTATE: În urma interpretării rezultatelor a fost identificată o corelație pozitivă între obiceiurile familiale și starea de bine psihologică a individului.

CONCLUZII: Aceste rezultate evidențiază importanța legăturii dintre interacțiunile de calitate din cadrul familiei și starea de bine psihologică.

Cuvinte-cheie: rutine familiale, ritualuri familiale, stare de bine psihologică

\section{Family routines: Implications for well-being}

\section{Abstract}

AIMS: This research aims to investigate the influence of family routines and rituals on individual psychological well-being.

METHODS: The method used was the completion of online scales (Family Routines Inventory, Ryff Psychological Well-Being Scale), evaluating the frequency and affective meaning of certain routines and rituals in the family of origin and the psychological well-being of the individual, and to observe the relationship between these variables in a sample of 129 subjects aged between 18 and 71, with medium-high socio-economic status. RESULTS: After the results were interpreted, a positive correlation between the family habits and psychological well-being was identified.

CONCLUSIONS: These results highlight the importance of the link between quality family interactions and psychological well-being.

Key-words: family routines, family rituals, psychological well-being.

* Corresponding Author: Sebastian Pintea, PhD, Department of Psychology, Babes-Bolyai University, 37 Republicii St., 400015, Cluj-Napoca, Romania, Tel./Fax:+40.264.590.967, Email: sebastianpintea@psychology.ro, Web: www.ubbcluj.ro, www.psiedu.ubbcluj.ro Article received: 2.10 .2021 , accepted: 15.10 .2021 , published: 20.10 .2021

Cite: Culea DG, Pintea S. Family routines: Implications for well-being. The Journal of School and University Medicine 2021;VIII(3):14-35 


\section{INTRODUCERE}

Familia reprezintă baza socializării individului (Grusec, \& Lytton, 1988). Mama, tatăl, frații, surorile, bunicii și chiar membri ai familiei extinse învață copilul ce trebuie să știe - cum să folosească obiecte, cum să relaționeze cu ceilalți, cum funcționează lumea. Prin felul în care am fost crescuți, ce am văzut, ce am învățat, ce ne-a fost validat în cadrul familiei de origine, ne este modelat comportamentul în societate. Modul în care se desfășoară interacțiunile din cadrul familiei poate oferi o imagine asupra modului în care individul funcționează în contexte mai largi. Mai departe, multitudinea de comportamente și atitudini umane din cadrul societății dictează cum se va forma societatea din care individul face parte. În cele din urmă, toate acestea se vor răsfrânge asupra stării de bine și funcționalității fiecăruia (Diener, 2000; Andrews, \& Withey, 2012).

Este esențial, deci, pentru a trăi într-un context satisfăcător, ca fiecare dintre noi să aibă parte de un cadrul familial sănătos. În interiorul unei familii sănătoase, membrii comunică și ascultă, se afirmă și sprijină reciproc, se învață respectul pentru ceilalți, ce e bine și ce e rău, dezvoltă un sentiment de încredere, au simțul umorului și al jocului, prezintă un sentiment de responsabilitate împărtășită, au un echilibru al interacțiunilor dintre ei, împărtășesc aceleași credințe religioase, își respectă intimitatea unul altuia, valorifică ajutorul acordat celorlalți, cer ajutorul atunci când au nevoie, au un puternic sentiment de familie datorită obiceiurilor şi tradițiilor și petrec timp de relaxare împreună (Curran, \& Curran, 1984).

Aceste obiceiuri familiale sunt văzute ca unul dintre cele mai puternice mecanisme ale socializării (Laird, \& Hartman, 1988) și au implicații atât directe pentru sănătatea familiei și starea de bine (Boyce, Jensen, Cassel, Collier, Smith, \& Ramey, 1977; Fiese, \& Kleine, 1993), cât și indirecte (Keltner, 1990; Brody, \& Flor, 1997; Kitsaras, Goodwin, Allan, Kelly, \& Pretty, 2018), motiv pentru care merită o atenție sporită. De asemenea, prezintă funcții importante precum comunicarea, reducerea conflictelor și crearea de legături pozitive (Huxley, 1966 citat în Crespo, Davide, Costa, \& Fletcher, 2008), sentimentul de securitate (Mead, 1973 citat în Crespo et al., 2008) și de apartenență la grup (Roberts, 1988 citat în Crespo et al., 2008), dar și transmiterea valorilor din generație în generație
(Erikson, 1966). Iar pentru că organizarea familiei s-a dovedit a fi asociată cu adaptarea psihologică în eșantioane clinice (Hauser et al., 1990; Dickstein, St. Andre, Sameroff, Seifer, \& Schiller, 1999; Santos, Crespo, Silva, \& Canavarro, 2012), ne așteptăm ca și în cazul indivizilor sănătoși să aibă un efect asupra adaptării.

Pe lângă diferențele interfamiliale așteptate, cultura joacă un rol important în exprimarea acestor obiceiuri, căci ele se bazează pe valorile promovate de aceasta, valori ce vizează indepentența și apartenența la grup (Martini, 1996; Blum-Kulka, 2012). Însă studiile care se focusează asupra acestor diferențe interculturale ale obiceiurilor familiale sunt puține, astfel că cercetătorii din acest domeniu recunosc nevoia de a investiga aceste obiceiuri în contexte culturale diferite (Baxter, \& Braithwaite, 2006; Evans, \& Rodger, 2008; Malaquias, Crespo, \& Francisco, 2015). Iar faptul că nu există niciun studiu care să investigheze obiceiurile familiale în contextul cultural românesc este unul dintre motivele principale pentru care am demarat această cercetare.

De asemenea, faptul că, în general, studiile s-au focalizat asupra familiilor cu situații speciale (Wolin, Bennett, Noonan, \& Teitelbaum, 1980; Guidubaldi, Cleminshaw, Perry, Nastasi, \& Lightel, 1986; Henry, \& Lovelace, 1995; Greene Bush, \& Pargament, 1997), crește importanța observării efectelor acestor obiceiuri și în eșantioane nonclinice, iar acesta este un alt motiv important care ne-a ghidat.

\section{OBICEIURILE FAMILIALE}

Interesul psihologiei asupra ritualurilor din familie s-a dezvoltat odată cu studiul realizat de Bossard și Boll în 1950, care urmărea contextul social, rasial și religios ale acestor ritualuri, cât și funcționalitatea lor, prin intermediul jurnalelor și interviurilor. Concluzia autorilor a fost că atitudinea unui individ față de aceste ritualuri este un indice destul de sigur al integrării sale în contextul din care face parte. Astfel, studiul a demonstrat că ritualurile au un rol foarte important în organizarea vieții familiale, promovând stabilitatea acesteia în perioadele dificile, caracterizate de stres sau tranziție (citat în Fiese, Tomcho, Douglas, Josephs, Poltrock, \& Baker, 2002) și, de asemenea, în transmiterea valorilor, atitudinilor și scopurilor de durată ale familiei (citat în Wolin, Bennett, 1984). 
De-a lungul timpului, studiul ritualurilor din familie s-a extins atât în domeniul clinic, cu scopul de a investiga rolul terapeutic pe care acestea le au, cât și în domeniul empiric, pentru a studia natura lor. Însă acest domeniu a fost dezvoltat în primă instanță cu scopul de a înțelege ce anume fac familiile în viața de zi cu zi, și cum anume aceste obiceiuri pot fi afectate negativ şi chiar desființate de evenimente și situații care produc stres în familie, precum alcoolismul, ori cum aceste obiceiuri pot proteja familia în astfel de cazuri (Palazzoli, Boscolo, Cecchin, \& Prata, 1977; Wolin, Bennett, \& Noonan, 1979; Wolin et al., 1980; Bennett, Wolin, Reiss, \& Teitelbaum, 1987; Bennett, Wolin, \& McAvity, 1988).

\section{Evoluția de la ritualuri sacre la ritualuri în familie}

Odată cu trecerea timpului și depărtarea de sacru, societățile, în evoluția lor, continuă să mențină credințe care au un rol asemănător cu religia. Moore și Myerhoff (1977) evidențiază importanța recunoașterii „sacralității“ din aceste credințe și ritualurile realizate în jurul lor. O serie de caracteristici şi proprietăți ale comportamentelor ritualice din societățile primitive au fost identificate de către antropologii culturali și prezentate în lucrarea lui Wolin și Bennett (1984). În primul rând, credințele sacre sau magice care stau la baza ritualurilor nu sunt puse la îndoială și sunt împărtășite de toți cei care participă. Aceste credințe sunt adesea exprimate sub formă de mituri, care sunt transmise într-o manieră stilizată, însă cu puternic impact afectiv, de obicei prin interpretări dramatice. În cadrul acestor interpretări, rolurile rămân constante. De asemenea, adoptarea ritualului are rolul de a crea un sentiment de legătură între participanți, iar identitatea formată ca grup este perpetuată prin repetarea interpretării de-a lungul timpului. Repetiția nesfârșită a ritualului întărește atât relațiile sociale din cadrul grupului, cât și legăturile culturale. În fine, ritualul reprezintă o experiență de învățare: fie că participă activ sau doar observă, individul este instruit privind locul lui în societate și este ajutat să înțeleagă relația dintre societatea din care face parte cu cultura ce o înglobează și cu întreg universul.

Toate aceste proprietăți subliniază importanța structurii și formei pentru mintea colectivă și demonstrează că oriunde s-ar ține ceremonia colectivă, aceasta are puterea de a transforma atitudinile grupului, de a elimina diferențele dintre membrii care, altfel, sunt în competiție și de a contura reguli comune pentru a promova coexistența. În societățile moderne, antropologii sociali au identificat noi contexte în care se aplică aceste caracteristici și proprietăți și susțin că, la nivel conștient, aceste ritualuri seculare se manifestă pe două niveluri: la cel mai conștient nivel, este scopul explicit pentru care ritualul a fost proiectat, iar la nivel inconștient, realizarea ritualului încorporează simbolurile grupului și recunoaște moștenirea sa comună (Wolin, Bennett, 1984).

\section{Tipuri de ritualuri}

În 1981, Reiss propune ideea că familiile întemeiază ritualuri și ceremonii care pot oferi coerență relațiilor din interiorul familiei, integrarea membrilor ca grup și situarea familiei în timp și spațiu. Astfel, familiile pot fi diferențiate prin felul în care își îndeplinesc și păstrează aceste ritualuri de-a lungul generațiilor.

În urma acestei idei, Wolin și Bennett (1984) publică lucrarea intitulată „Family rituals“ cu scopul de a prezenta semnificația și implicațiile acestor ritualuri, prea puțin studiate și vag definite până atunci. În cadrul acestei lucrări, cei doi autori definesc ritualurile familiare drept „o formă simbolică de comunicare, care datorită satisfacției trăite de membrii familiei în urma repetiției, în timp devine acționată în mod sistematic. Prin semnificația lor specială și natura lor repetitivă, ritualurile contribuie în mod semnificativ la stabilirea și conservarea sensului colectiv al familiei în sine, numit identitate familială. Ritualurile stabilizează această identitate pe tot parcursul vieții de familie, prin clarificarea rolurilor expectate, stabilirea limitelor din cadrul și din afara familiei și definirea unor reguli, astfel încât toți membrii să știe că «așa este familia noastră»." (Wolin, \& Bennett, 1984, p. 1).

Autorii propun împărțirea acestor ritualuri în trei mari categorii: celebrări familiale, tradiții familiale și interacțiuni familiale care urmează un tipar (en. patterned family interactions) și le definesc astfel:

Celebrările familiale sunt reprezentate de vacanțele și ocaziile răspândite în cultura de care aparține familia, având o semnificație specială pentru aceasta. În această categorie intră ritualurile de trecere, 
precum nunta, înmormântarea, baptismul; celebrări religioase anuale ca Paștele, Crăciunul și sărbătorile laice precum Anul Nou. Prin repetarea în timp a acestor ritualuri se consolidează stabilitatea. Acest tip de ritualuri se disting prin natura lor standardizată în majoritatea familiilor dintr-o anumită societate, prin faptul că, de obicei, sunt tipice unei subculturi și prin universalitatea simbolurilor care aparțin ritualului. Din aceste motive, familia care nu manifestă câteva astfel de ritualuri este atipică. Cu ocazia acestor celebrări, indivizii au posibilitatea de a împărtăși ocaziile speciale cu familia și prietenii, iar astfel familiei nucleare îi este asigurată identificarea cu grupul mai mare. În acest fel, ritualurile realizate transmit atât comunitatea familiei cu cultura, cât și unicitatea ei.

La acest tip de ritualuri, soții trebuie să negocieze într-o anumită măsură formatul pe care îl vor urma aceste festivități în cadrul familiei, ținând cont de experiențele lor din familia de origine. Individual, fiecare poate avea sentimente mai mult sau mai puțin pozitive în legătură cu celebrările din familia lor, dar, cu toate acestea, nu se obișnuiește să se dezbată semnificația lor emoțională.

Spre deosebire de celelalte, ritualurile de trecere au funcții specifice: celebrările precum botezul, nunta sau înmormântarea ajută la conturarea imaginii membrilor care aparțin familiei, în timp ce evenimentele precum absolvirea marchează etapa de dezvoltare a familiei.

Tradițiile familiale, pe de altă parte, sunt mai puțin legate de cultură și mai mult legate de particularitățile fiecărei familii în parte. Astfel, acestea nu apar cu frecvența vacanțelor sau în modul standardizat tipic ritualurilor de trecere, însă reapar în majoritatea familiilor cu o oarecare regularitate. $\mathrm{O}$ altă diferență între cele două categorii este felul organizării - tradițiile sunt organizate în mod moderat, spre deosebire de nivelul crescut de organizare al celebrărilor. Aici, fiecare familie are propriul set de tradiții, iar de obicei din această categorie fac parte vacanțele de vară, vizitele ce implică familia extinsă, zile de naștere și aniversări etc.

Deși cultura contribuie la modelarea acestor tradiţii (de exemplu, prin elemente precum tortul aniversar sau felicitările aniversare), fiecare familie alege ocaziile pe care le va sărbători, motiv pentru care membrii familiei le acordă o semnificație crescută acestora și sunt atașați de respectarea continuă a lor. De asemenea, există variații între familii privind diferite aspecte ale acestor tradiții adoptate, de la măsura în care se centrează pe copilul familiei atunci când organizează vacanța, până la măsura în care implică indivizi din afara familiei în cadrul acestor celebrări. Prin intermediul acestor tradiții se transmite identitatea familială, un fel de a spune „Așa suntem noi, așa este familia noastră“.

Interacțiunile familiale sunt cele mai frecvent realizate și, în același timp, cel mai puțin planificate în mod conștient. Acestea sunt rutinele de dormit pentru copii, cina luată în mod regulat, activități de petrecere a timpului liber în weekend ori seara, felul în care sunt tratați oaspeții din casă, saluturile zilnice, disciplina copiilor - cele mai puțin intenționate și mai ascunse dintre toate tipurile de ritualuri. Scopul acestor interacțiuni este de a ajuta la definirea rolurilor și responsabilităților membrilor familiei și reprezintă un fel de a organiza viața de zi cu zi.

În general, activitățile de seară și din weekend din cadrul familiei oferă un prilej de a-și stabili comportamente ritulice regulate. Iar cu toate că orele de relaxare par să fie lipsite de planificare sau simbolizare intenționată, în interacțiunile de rutină familia va ajunge să stabilească ritualuri care vor exprima convingerile împărtășite și identitatea comună.

În baza acestei categorizări, Steinglass, Bennett, Wolin și Reiss (1987, citat în Viere, 2001) fac distincția între cinci tipuri de ritualuri: ritualuri delimitate, care sunt pregătite cu anticipare și au un început, mijloc și sfârșit clare; ritualuri identificabile, în care familiile sunt conștiente de ritualurile lor şi pot descrie cu claritate organizarea și desfășurarea acestora; ritualuri coercitive, pentru care familiile fac eforturi de menținere, ritualuri simbolice, care sunt asociate cu sens și emoții puternice și ritualuri organizatorice, care sunt reglatori principali ai stabilității în vieții de familie.

\section{Proprietățile ritualurilor familiale}

Ritualurile sunt o formă de educare a membrilor grupului și de reglare a comportamentelor acestora prin împărtășirea credințelor și perpetuarea lor în timp. Astfel, le oferă membrilor ocazia de a-și confirma identificarea cu ceilalți și de a experimenta și sărbători identitatea familiei, care transcende limitele individuale. 
Wolin și Bennett (1984) identifică trei proprietăți ale ritualurilor care acționează împreună pentru a contura, afirma și menține identitatea familiei.

\section{a. Transformarea}

Aceasta se manifestă prin evenimentele pregătitoare care constituie o perioadă de tranziție, un pasaj de la nonritual la ritual. Vorbind despre ritualurile de trecere, Turner $(1969 ; 2017)$ numește această tranziție „perioadă liminală“ - o perioadă în care nu suntem ceea ce am fost înainte de ritual și nu suntem încă ceea ce vom deveni după ce ritualul va fi iniţiat.

Transformarea se desfășoară astfel: membrii familiei încep în starea nonrituală a vieții de zi cu zi, apoi intră într-o stare pregătitoare, anticipând executarea propriu-zisă. Ritualul începe apoi cu toți participanții fiind foarte conștienți de scopul lor și de conexiunea dintre ei și îndeplinind roluri într-un mod foarte clar și exact. Pe măsură ce ritualul se încheie, membrii familiei se îndepărtează, iar sentimentul crescut de conștientizare se diminuează (Wolin, \& Bennett, 1984).

Această tranziție este cea mai vizibilă în cadrul ritualurilor de trecere, în care tranziția este prescrisă în mod formal și executată în mod simbolic, cum este furatul miresei sau procesiunea funerară. Se poate observa, însă, și în celebrările familiale, în momente precum cel în care se stinge lumina la ziua de naștere în așteptarea tortului cu lumânările aprinse, ori atunci când casa este încuiată, bagajele sunt în mașină, copiii sunt pe bancheta din spate și întreaga familie este oficial în vacanță. În același fel, și o seară obișnuită acasă poate avea etapa ei tranzițională, cum este momentul când soții se așteaptă acasă și discută despre ziua pe care au avut-o, ascultându-și impresiile și opiniile.

Turner (1977 citat în Wolin, \& Bennett, 1984) spune că acest proces laminal sau de transformare produce experiența de communitas între participanți: „Persoane care sunt similare într-o caracteristică importantă ca sexul, vârsta, etnia, religia sau în posesia unei condiții fizice sau mentale comune... se retrag simbolic, ba chiar cu adevărat, din întregul sistem de care, într-o anumită măsură, se pot simți înstrăinați, pentru a căuta strălucirea comuniunii printre cei cu care împărtășesc vreo caracteristică culturală ori biologică pe care o vor folosi ca cel mai semnificativ semn al identității lor“ (pag. 47).
Datorită sentimentului crescut de identificare cu grupul, importanța limitelor individuale este minimizată. În communitas, spune Turner, rolurile individuale sunt reduse și identitatea tribală este crescută. În cadrul ritualurilor familiale se promovează acelaşi tip de transformare: coeziunea biologică și culturală a familiei face un mediu stimulant pentru apariția și consolidarea comuniunii. Chiar și conceptul de „identitate familială“ poate fi văzut ca o formă specială a comuniunii (Wolin, \& Bennett, 1984).

\section{b. Comunicarea}

Wolin și Bennett (1984) susțin că, în rolul de proprietate a ritualului, comunicarea ia două forme distincte, dar care interacționează de cele mai multe ori: comunicarea afectivă şi comunicarea simbolică.

Ritualul promovează comunicarea prin declanşarea unui afect puternic. Astfel, toate ritualurile de trecere au drept funcție comună această comunicare afectivă, la fel cum și rutinele o prezintă, însă într-o manifestare mai subtilă - permițându-le indivizilor să-și exprime sentimentele în siguranța pe care o asigură convențiile ritualului. Putem observa această manifestare în ritualurile de culcare, de exemplu, care pot fi văzute ca un mijoc de face față anxietăţii datorate despărtirii pe parcursul nopții, atât pentru copii, cât și pentru părinți. În aceeași notă, ritualurile de evadare, precum vacanțele, weekend-urile și activitățile relaxante de pe parcursul serii au aceeaşi funcție adaptativă de ,safety valves“ pentru familie. Chiar și în familiile care nu au prea multe ritualuri este prezent acest tip de comunicare. Simplul fapt de a se întâlni în aceeași parte a zilei cu un scop comun poate avea puternice conotații afective - în cadrul studiului lor, Wolin și Bennett (1984) au remarcat că la întrebarea ce viza cel mai important aspect al cinei în viața lor, subiecții răspund cu o consistență surprinzătoare că acesta este doar faptul de a fi împreună, ca o familie. Iar în contextul familiei, prin activitățile ritualice, există nenumărate oportunități pentru manifestarea aceastei forme speciale de exprimare emoțională, autorii considerând că are chiar și o funcție terapeutică.

Pe de altă parte, comunicarea simbolică are rolul de a-i oferi un sens ritualului. Familiile folosesc multe simboluri în cadrul ritualurilor realizate, de la modul în care este aranjată masa la cina de Crăciun, la alegerea mâncării, felul în care participanții se 
îmbracă, obiceiurile de dăruire de cadouri - toate comunicând fapte și mituri despre familie și moștenirea sa, dar și atașamentul familiei față de trecut. De asemenea, aşa cum se manifestă prin intermediul obiectelor, acest tip de comunicare poate fi remarcată și în comportament. De exemplu, felul în care sunt așezați invitații poate determina ce povești sunt împărtășite de către cine, iar interacțiunile dintre membrii pot simboliza relații de putere, legături între generații sau conflicte nerezolvate. Astfel, fiecare familie stabilește ce este simbolic pentru grupul său și confirmă validitatea simbolurilor de fiecare dată când ritualul se repetă. Chiar și cele mai puțin elaborate interacțiuni familiale care urmează un tipar pot demonstra funcția simbolică a comunicării din cadrul ritualurilor, la fel cum prezența sau absența anumitor membri ai familiei reprezintă un simbol evocativ puternic al vieții de familie. Ritualurile de familie reușesc astfel să comunice asumpții comune despre relații și să le inspire membrilor regulile de înțeles comun pentru comportamentul lor (Wolin, \& Bennett, 1984).

\section{c. Consolidarea}

Odată ce ritualul este repetat într-o manieră familiară de-a lungul timpului, familia are parte de această consolidare, iar prin transmiterea acestuia generației următoare, familia își asigură un soi de nemurire. Observarea ritualurilor asigură predictibilitatea vieții de familie prin simplul fapt că oferă structură evenimentelor, iar astfel, în fața schimbărilor externe, reprezintă un mod stabil de recunoaștere a familiei. Deși familiile câștigă și pierd membri, ritualul în sine este un manifest al continuității împotriva schimbării - în fiecare an, aceeași mâncare, aceiași invitați, aceleași glume.

Consolidarea ritualului are loc pe două planuri: aici și acum - ritualul reprezintă o ancoră pentru familie, o bază pe care se construiește în căutarea echilibrului între nou și familiar, între spontan și intenționat; și ritualul ca legătură între trecut, prezent și viitor: vedem această dimensiune în practicile transmise și adaptate de la generație la generație, cu asumpția implicită că descendenții vor repeta același procedeu. Continuitatea de la trecut la prezent poate lua forme foarte diferite, de la vizibilă și evidentă, ca atunci când se utilizează aceleași obiecte, la mai puțin evidentă, de exemplu prin rutine reînnoite de membrii a două generații, ori foarte subtilă, prin perpetuarea rolurilor familiei în timp (Wolin, \& Bennett, 1984).

\section{Tipologiile ritualizării}

Fiecare familie variază în realizarea ritualurilor, astfel că, în unele familii, acestea sunt acceptare și încurajate, în timp ce în altele nu sunt valorizate ca activități familiale importante. În baza acestor distincții, autorii identifică două dimensiuni care determină nivelul general de ritualizare al familiei: angajamentul de a utiliza ritualul în stabilirea și menținerea identității familiale și adaptabilitatea - capacitatea familiei de a adapta ritualurile de la o etapă de dezvoltare a familiei la alta. Acestea sunt funcții independente, fiecare influențând nivelul general de practicare al ritualurilor al familiei la un moment dat (Wolin, \& Bennett, 1984).

Diferențele individuale își spun cuvântul și în acest aspect al existenței, astfel că fiecare familie tinde să își dezvolte un anumit stil de ritualizare. Roberts (1988, citat în Fiese, \& Wamboldt, 2000) identifică sașe tipuri de utilizare a ritualurilor în familie: $s u$ britualizarea (familia practică rareori ritualurile familiale, adesea ignorând repere importante, precum aniversări sau zile de naștere); ritualizarea rigidă (familia prestabilește reguli stricte de conduită și deține așteptări mari privind participarea tuturor membrilor); ritualizarea oblică (en. skewed ritualization; atunci când practicile ritualice sunt legate în principal de un membru al familiei sau de un aspect al vieții familiei, ca religia sau etnia); ritualul gol (atunci când oamenii sărbătoresc ceva din obligație, cu puțină implicare afectivă); ritualul întrerupt (sau care nu poate fi experiențiat deschis - se întâmplă din cauza unor schimbări bruște sau evenimente traumatice din cadrul familiei, precum moarte, boală, iar familia poate fi incapabilă să asimileze întreg procesul ritualului) și ritualul flexibil (familia menține aspectul simbolic semnificativ al ritualurilor și este capabilă să adapteze rolurile și rutinele pe parcursul ciclului vieții familiei).

\section{Dimensiunile ritualurilor familiale}

Fiese (1992) indentifică iniţial șase dimensiuni ale ritualurilor familiale: apariția, care se referă la frecvența activității, cât de des apare aceasta; rolurile implicate, atribuirea acestora și a îndatoririlor asociate lor; rutina, care se raportează la regularitatea din 
felul în care se desfãşoară respectiva activitate; prezența, mai specific așteptările privind obligativitatea prezenței la activitate; investiția emoțională asociată activității (afectul) și semnificația simbolică reprezentată prin oferirea unui sens activității respective. Ulterior, Fiese și Kleine (1993) întregesc imaginea ce compune ritualul familial prin adăugarea a două noi dimensiuni: continuarea și premeditarea. Prin continuare înțelegem persistența activității de-a lungul generațiilor, în timp ce premeditarea se referă la pregătirea și planificarea în avans asociate activității.

$\mathrm{O}$ ultimă delimitare conceptuală privind dimensiunile componente ale ritualurilor familiale a fost realizată de către Schuck și Bucy în 1997. Autorii compun ritualul din patru dimensiuni: structură, sens, peristență și adaptabilitate.

Structura înglobează componentele-cheie ale ritualurilor, și anume ce sunt, când și unde apar și cine este prezent. Sensul este dat de nivelul de semnificație afectivă, emoție și de simbolistică asociate ritualului, dimensiune echivalentă cu semnificația simbolică și afectivă din modelul propus de Fiese (1992). Persistența se referă, aici, la menținerea consecventă a ritualului, care poate fi întreruptă de schimbări bruște sau evenimente traumatice, iar adaptabilitatea se referă la abilitatea de menținere a ritualurilor de-a lungul timpului prin adaptarea lor în funcție de noile nevoi.

\section{Ritualuri și rutine}

Ritualurile reprezintă un comportament social, prestabilit, care se repetă de-a lungul timpului și este împărtășit de membrii unui grup social, fiind o formă de manifestare care are și un alt sens pe lângă cel instrumental, pragmatic, o construcție simbolică care afirmă ceva de valoare transcendentă (Boyce, Jensen, James, \& Peacock, 1983). Orice rutină, astfel, are potentialul teoretic de a dobândi statutul de ritual odată ce trece de la funcția pur instrumentală la una cu încărcătură simbolică.

Interacțiunile tipice din cadrul familiei, care se repetă și urmează un pattern - a treia categorie a ritualurilor familiale din modelul lui Wolin și Bennett (1984) - sunt cel mai des confundate cu rutinele din cauza funcției lor instrumentale de la suprafață, fiind activități obișnuite. Însă aceste interacțiuni sunt, de fapt, ritualuri. Datorită semnificației simbolice, acestea trec de limitele rutinelor de zi cu zi, dobândind o semnificație mai profundă.

Fiese și colaboratorii $(2002 ; 2006)$ fac diferențierea între ritualuri și rutine pe trei dimensiuni: $c o-$ municare, angajament și continuitate. Din punct de vedere al comunicării, rutinele implică comunicare instrumentală care transmite ceva ce trebuie făcut ori atribuirea unor roluri. Ritualurile, pe de altă parte, implică comunicare simbolică și cu încărcătură emoțională, ce transmite identitatea grupului. Porecle, glume pe care le știu doar membrii familiei, termeni de alint - toate întăresc rolul individului în grup și au o semnificaţie pentru toți membrii. Angajamentul rutinelor este temporar, se focalizează pe sarcină în sine, iar odată ce acțiunea este finalizată, există puține gânduri ulterioare legate de ea, în timp ce angajamentul ritualurilor este afectiv și lasă individul cu sentimentul de apartenență și de potrivire, că este unde trebuie să fie. Legăturile emoționale create în cadrul întâlnirilor repetitive sunt reluate în memorie în repetate rânduri, contribuind la acel sentiment de apartenență la un grup care poate semnifica un refugiu sigur. Privind continuitatea, rutinele se repetă în timp și sunt recunoscute prin continuitatea în comportament, însă ritualurile oferă continuitatea sensului între generații, anticipându-se repetarea acestora și consolidându-se identitatea familială.

Există însă un prag foarte fin care face trecerea de la rutine la ritualuri, iar acest fenomen poate fi observat în cadrul cinei luate în familie, de exemplu. Conversațiile de grup ce includ glume pe care le știe doar familia, porecle, obiecte simbolice, reacția afectivă implicată atunci când se adună toți membrii, ori elemente transmise din generațiile anterioare, precum vase, rugăciuni sau subiecte de conversație, toate aceste elemente contribuie la omagierea identității familiale. Când rutina reușește să ofere o reprezentare simbolică a identităţii familiale, pe lângă rolul pragmatic de element organizatoric în viața de familie, atunci putem spune că a atins statutul de ritual (Boyce et al., 1983). Astfel, reprezentarea acestora poate fi văzută ca un continuum, cu rutine care devin ritualuri atunci când dezvoltă implicaţii emoționale și un înțeles mai profund pentru familie (Evans, \& Rodger, 2014). Iar în timp, așa cum rutinele se pot dezvolta în ritualuri, și ritualurile pot reveni la statutul de rutine (Wolin, \& Bennet, 1984). 


\section{Relația dintre obiceiurile familiei și funcționalitatea acesteia}

În continuare vom utiliza conceptul de „obiceiuri familiale" pentru a îngloba ritualurile și rutinele cu semnificație afectivă din cadrul familiei.

Există un număr mare de studii care atestă valoarea pozitivă a obiceiurilor familiale pentru funcționalitatea familiei. Sprunger, Boyce și Gaines (1985) arată că rutinele sunt un indicator al adaptării familiei și al competenței parentale percepute a mamei în perioada apariției unui sugar în familie. În cadrul acestui studiu, mamele copiilor mici au raportat o satisfacție crescută cu rolul de părinte și, de asemenea, o competență declarată mai mare, atunci când în cadrul familiei există rutine. Un studiu longitudinal încheiat în 2019 (Barton, Brody, Yu, Kogan, Chen, \& Ehrlich) subliniază aportul unic pe care aceste obiceiuri familiale le au asupra funcționalității pe termen lung: cu cât există mai multe rutine în familie în perioada adolescenței, cu atât nivelele epinefrinei și consumului de alcool vor fi mai scăzute, iar nivelele de auto-reglare emoțională și înscriere în programe educaționale în perioada de adulți tineri vor fi mai crescute.

Rutinele familiale au influențe și asupra sănătății copiilor. În acest sens, studiile arată că în familiile cu rutine regulate, infecțiile respiratorii la sugari durează mai puțin (Boyce, Jensen, Cassel, Collier, Smith, \& Ramey, 1977), copiii care au rutine de somn regulate se trezesc pe parcursul nopții cu o frecvență mai redusă, comparativ cu copiii care nu dispun de astfel de rutine (Seymour, Brock, During, \& Poole, 1989), iar nivelele mai ridicate ale rutinelor familiale și mediul de acasă mai stimulant corelează semnificativ cu sănătatea copilului (Keltner, 1992).

Cercetările arată că menținerea obiceiurilor familiale în perioade de separare (divorț, recăsătorie), facilitează o adaptare mai bună a copiilor (Guidubaldi, Cleminshaw, Perry, Nastasi, \& Lightel, 1986; Portes, Howell, Brown, Eichenberger, \& Mas, 1992), la fel cum se întâmplă și în cazul celor cu familii monoparentale (Brody, \& Flor, 1997). Aceste obiceiuri au rol protector în transmiterea alcoolismului (Wolin et al., 1980; Bennett et al., 1987), iar studiul lui Keltner (1990) arată că preșcolarii ale căror familii au rutine prezintă niveluri mai ridicate de interes și participare în programele preșcolare, cât și comportamente cooperative și compliante.

Fiese și colaboratorii (2002) speculează apariția unei posibile tranzacții între părinte și copil, în sensul că, acolo unde există obiceiuri familiale, comportamentul copilului este mai bine reglat, iar mai departe este influențată competența parentală.

Privind adolescenții, obiceiurile familiale influențează atât sănătatea (Compañ, Moreno, Ruiz, \& Pascual, 2001), cât și adaptarea psihologică pentru cei din familii nucleare (Eisenberg, Olson, NeumarkSztainer, Story, Bearinger, \& 2004; Malaquias, Crespo, \& Francisco, 2015), dar și pentru cei cu părinți recăsătoriți (Henry, \& Lovelace, 1995; Braithwaite, Baxter, \& Harper, 1998), starea de bine (Eisenberg et al., 2004; Crespo, Kielpikowski, Pryor, \& Jose, 2011) și dezvoltarea identității (Fiese, 1992) și pot avea rol protector în dezvoltarea comportamentelor de risc (Fulkerson, Story, Mellin, Leffert, Neumark-Sztainer, \& French, 2006).

Obiceiurile familiale au o importanță crescută și pentru satisfacția maritală (Fiese, Hooker, Kotary, \& Schwagler, 1993), calitatea relaţiilor de cuplu și apropierea dintre parteneri (Crespo, Davide, Costa, \& Fletcher, 2008), adaptarea psihologică în cazul depresiei maternale (Dickstein, St. Andre, Sameroff, Seifer, \& Schiller, 1999), dar și pentru sentimentul de apartenență la grup și identitatea personală (Bennett et al., 1988; Cheal, 1988; Jensen, James, Boyce, \& Hartnett, 1983). În cazul pacienților cu durere cronică, impactul durerii asupra familiei este redus, iar rezultatele raportate de pacienți sunt mai pozitive atunci când există aceste obiceiuri în contextul familial (Greene Bush, \& Pargament, 1997).

\section{Starea de bine psihologică}

De-a lungul timpului, s-au dezvoltat două mari perspective privind starea de bine a individului: perspectiva hedonică și cea eudaimonică. Încă din antichitate, Aristippus, filozof grec, propune ideea că scopul vieții este de a avea parte de cantitatea maximă de plăcere, iar fericirea reprezintă totalitatea momentelor hedonice trăite de individ (Ryan, \& Deci, 2001). Ideea lui a fost urmată și dezvoltată și de alți filozofi, printre care și Hobbes, care spunea că fericirea stă în îndeplinirea cu succes a căutării poftelor noastre umane și De 
Sade, care susținea că urmărirea senzațiilor și plăcerii este scopul final al vieții (Airaksinen, 2002).

Din punct de vedere psihologic, adepții hedonismului se referă la acest termen în sens mai larg, evidențiind și importanța plăcerilor intelectuale, pe lângă cele fizice (Kubovy, 1999). Astfel, starea de bine este reprezentată de fericirea subiectivă, având baza în experențierea plăcerii și evitarea neplăcerii, însă nu poate fi redusă doar pe plan fizic, căci poate apărea în urma atingerii anumitor obiective ori rezultate valorificate de individ în anumite sfere de interes (Diener, Sapyta, \& Suh, 1998).

Teoreticienii acestei perspective evaluează experiența umană prin starea de bine subiectivă (SWB, en. subjective well-being), ceea ce poate fi dificil, deoarece conceptul de „viață bună“ variază considerabil între indivizi (Diener, \& Lucas, 1999). În evaluarea acestui construct, specialiștii includ atât evaluările cognitive privind satisfacția cu viața, cât și evaluările afective ale stărilor și emoțiilor. Astfel, satisfacția cu viața, prezența afectului pozitiv și lipsa afectului negativ constituie „fericirea“, cum adesea este numită această stare de bine subiectivă (Diener, \& Lucas, 1999).

Această abordare a stării de bine a cauzat dezbateri privind adecvarea măsurării acestui concept prin SWB, atât din cauza validităţii acestuia și a măsurătorilor asociate, cât și din cauza ambiguității tipurilor de activități, scopuri și realizări care, teoretic, ar trebui să promoveze starea de bine (Ryan, \& Deci, 2001). Însă ca răspuns la critici, susținătorii perspectivei hedonice susțin ideea că cercetarea SWB le permite indivizilor să împărtășească cu cercetătorii ce anume le face viața bună, în timp ce abordarea eudaimonică le permite cercetătorilor să contureze starea de bine (Diener et al., 1998).

Chiar din perioada Antichității, au existat voci care s-au opus acestei abordări, formându-se, astfel, perspectiva eudaimonică, bazată pe dezvoltarea potențialului uman care, în fine, va duce la o calitate crescută a vieții (Ryff, 1995). De exemplu, Aristotel (1985, pag. 7, citat în Waterman, 1990) considera fericirea hedonică un ideal vulgar care îi face pe oameni înrobiți de propriile dorințe: „Gloata, cei mai vulgari, aparent concep binele și fericirea ca plăcere, și prin urmare le place o viață de satisfacții. Aceștia apar complet sclavi, întrucât viața asupra căreia se decid este o viață de animale de pășune“, și a propus ideea că adevărata fericire se află în expresia virtuții, adică făcând acele lucruri care merită.

Teoria eudaimonismului îndeamnă individul să își recunoască propriul daimon sau „sine adevărat" (en. true self) și să trăiască în concordanță cu acesta (Norton, 1976, citat în Waterman, 1993). Astfel, teoriile bunăstării eudaimonice susțin că nu toate rezultatele valorificate de individ, sau dorințele lui, ar produce stare de bine atunci când sunt îndeplinite. $\mathrm{Cu}$ alte cuvinte, deși produc plăcere, unele dintre ele nu fac bine individului și nu promovează bunăstarea. Ideea generală a acestor teorii este că fericirea subiectivă nu poate fi echivalată cu starea de bine (Ryan, \& Deci, 2001).

Waterman (1993) susține că eudaimonia apare atunci când activitățile din viețile oamenilor sunt cele mai congruente ori conectate cu valorile lor profunde, există o implicare deosebită în activitate și un sentiment de împlinire, pe care el le înglobează sub numele de „expresivitate personală“. În cadrul acestei lucrări, Waterman arată că fericirea hedonică și expresivitatea personală prezintă o corelație puternică, însă indică tipuri distincte de experiențe.

\section{Modelul multidimensional al lui Ryff}

Ryff descrie starea de bine ca „efortul spre perfecțiune care reprezintă realizarea adevăratului potențial“ (1995, p. 100) și prezintă această stare de bine psihologică (PWB, en. psychological well-being) ca fiind distinctă de SWB (Ryff, \& Keyes, 1995). Starea de bine psihologică a primit atenție din partea a trei mari abordări teoretice (Ryff, 1995): psihologia dezvoltării prezintă starea de bine ca progresele de dezvoltare continuă de-a lungul vieții și include modelul stadiilor de dezvoltare psihosocială al lui Erikson, tendințele de bază care se activează cu scopul împlinirii vieții identificate de Bühler și descrierile schimbărilor personalității în perioada adultă și la bătrânețe realizate de Neugarten. Din partea psihologiei clinice, există abordarea lui Maslow de auto-actualizare, individul pe deplin funcțional conturat de Rogers, procesul de individualizare al lui Jung și conceptul de maturitate formulat de Allport. Iar literatura care vizează sănătatea mentală prezintă criteriile pozitive ale sănătății mentale realizate de Jahoda și concepția lui Birren despre funcționarea pozitivă în mai târziu în viață. 
În urma impactului redus ale acestor abordări în lumea empirică asupra stării de bine psihologice, Ryff (1989a) propune un model multidimensional care înglobează aceste perspective și identifică punctele lor de convergență, ilustrate în figura 1 (Ryff, 1995):

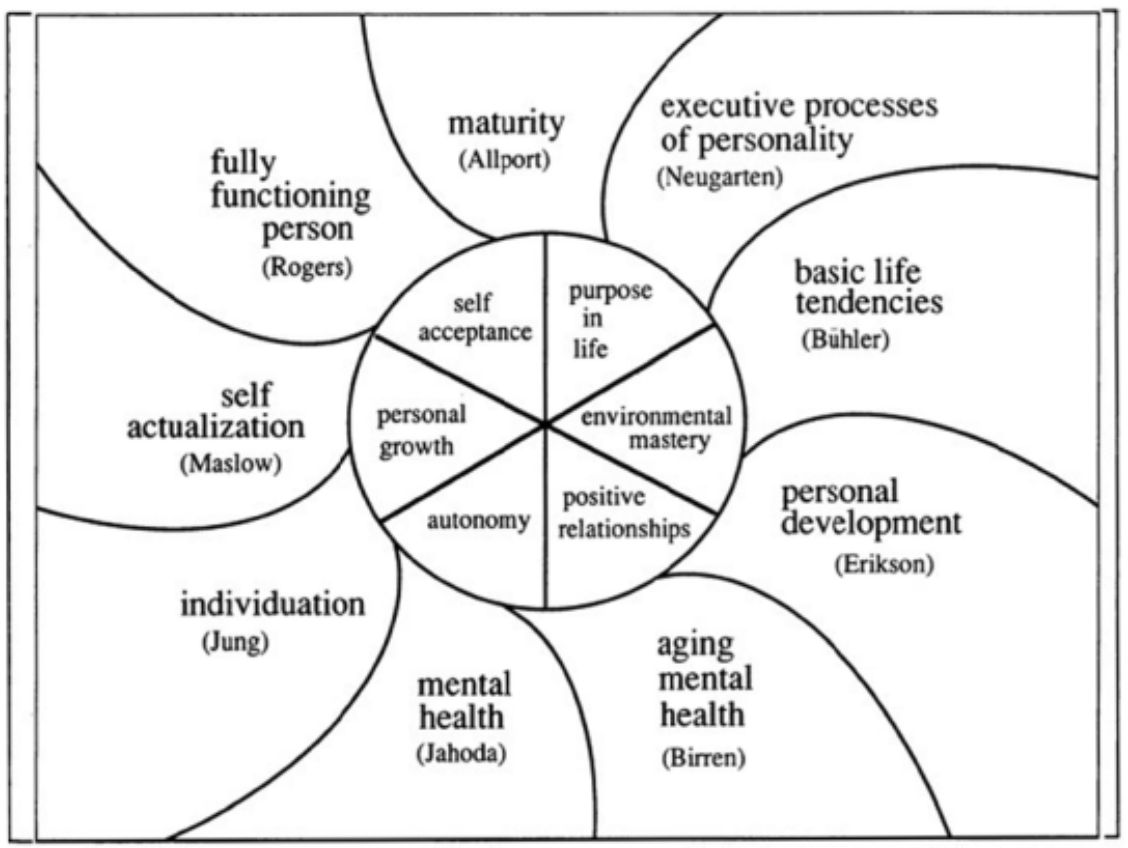

Ryff (1989a) motivează structura multidimensională a stării de bine psihologice astfel:

Autoacceptarea este tema cea mai recurentă din domeniul funcționării pozitive, întâlnită atât în teoria autoactualizării a lui Maslow, ca acceptare generală a naturii, a celorlalți și a sinelui, la Rogers, ca perceperea propriului sine ca fiind de valoare, cât și la Allport, care o descrie drept „securitate emoțională“ în abordarea lui asupra maturității. Și Jung vorbește despre autoacceptare sub forma recunoașterii anumitor elemente ale propriului sine, precum natura feminină și masculină, ori partea bună și rea. În teoria stadiilor dezvoltării a lui Erikson aceasta apare în stadiul de integritate a eului, unde este evidențiată atât autoacceptarea, cât și acceptarea propriului trecut și a realizărilor și eșecurilor de pe parcursul vieții. Jahoda prezintă atitudinea pozitivă față de sine, compusă din autoacceptare, încredere în sine și sprijinul propriu, drept primul criteriu al sănătății mentale, iar Birren și Renner subliniază faptul că cei care îmbătrânesc pozitiv au parte de o congruență mai mare între sinele adevărat și sinele ideal. Astfel, o atitudine pozitivă față de sine și propria viață este un element de convergență în literatura care vizează funcționarea pozitivă, reprezentând, deci, un criteriu esențial al stării de bine. În modelul multidimensional al lui Ryff (1989a), o persoană cu un nivel crescut de autoacceptare are o atitudine pozitivă față de sine, își recunoaște și acceptă atât părțile bune, cât și cele rele și este împăcat cu viața pe care a dus-o până în prezent. Pe de altă parte, un nivel scăzut al autoacceptării implică nemulțumire de sine, neliniște privind anumite trăsături personale, dezamăgire în legătură cu propriul trecut și dorința de a fi diferit față de sinele real.

Relațiile pozitive cu ceilalți, caracterizate de căldură și încredere, reprezintă un alt element de bază în majoritatea teoriilor amintite. În teoria lui Maslow, cei care ating auto-actualizarea sunt prezentați ca având interese sociale și ca fiind capabili de o iubire mai măreață, relații de prietenie mai profunde și de o identificare cu ceilalți mai completă decât cei care nu ajung la auto-actualizare. Pentru Rogers, individul pe deplin funcțional prezintă o încredere de bază în natura umană, iar Allport include căldura față de ceilalți în criteriile maturității, descriind persoana matură ca fiind capabilă de o intimitate crescută în dragoste, atât cu membrii familiei sau prietenii, dar și de a manifesta compasiune, respect și apreciere față de alții. Stadiile adulte din teoria lui Erikson implică provocări ce țin de relațiile interpersonale, cum este atingerea intimităţii 
și generativității. Și în criteriile sănătății mentale ale lui Jahoda se pune accent pe abilitatea de a iubi și pe adecvarea în relațiile interpersonale, iar Birren și Renner afirmă că sănătatea mentală implică abilitatea de a răspunde altor indivizi, de a iubi, de a fi iubit și de a face față relațiilor de compromis cu ceilalți. Prin urmare, relațiile pozitive cu ceilalți sunt un alt element-cheie al modelului integrativ propus de Ryff, caracterizat de relații calde, satisfăcătoare și de încredere cu ceilalți, preocupare privind bunăstarea celorlalți, empatie, afecțiune și intimitate puternice și înțelegerea compromisurilor specifice relațiilor umane. La pol opus este profilul cu puține relații apropiate și de încredere, care consideră dificil să fie deschis, preocupat și cald cu ceilalți, este izolat și frustrat în relațiile interpersonale și nu este dispus să facă vreun compromis pentru a păstra legăturile importante.

Autonomia este descrisă în teoria lui Maslow ca o caracteristică esențială a individului auto- actualizat, atât în funcționarea autonomă a acestuia, cât și în abilitatea lui de a rezista presiunilor sociale de a gândi și acționa într-un anume fel. Individul pe deplin funcțional al lui Rogers nu caută aprobare din partea celorlalți, ci are un locus de evaluare intern, bazându-se pe standardele personale, în timp ce Jung sustine că dezvoltarea personalității implică eliberarea de convenții, în sensul că individul nu va mai rămâne agățat de fricile, credințele și legile colective. Și Neugarten vorbește despre libertatea față de evaluările altora, însă o prezintă sub forma unei caracteristici a procesului de interiorizare, acesta reprezentând o schimbare în personalitate la bătrânețe. Jahoda se referă la autonomie drept auto-determinare, independență și reglarea comportamentului din interior și face parte din criteriile sănătății mentale. Ryff (1989a) menționează aici și teoria dezvoltării eului a lui Loevinger, în care autonomia reprezintă unul dintre stadiile finale ale dezvoltării. În baza acestor teorii care evidențiază importanța autonomiei pentru starea de bine psihologică, aceasta devine o nouă dimensiune a modelului lui Ryff, care definește persoana autonomă ca auto-determinată și independentă, capabilă să reziste presiunilor sociale de a gândi și acționa în feluri prestabilite, își reglează comportamentul din interior și se auto-evaluează conform propriilor standarde. Un individ cu un scor scăzut al autonomiei este preocupat de așteptările și evaluările celorlalți, se bazează pe judecățile altora pentru a lua decizii importante și se conformează presiunilor sociale de a gândi și acționa într-un anumit fel.

Controlul mediului este observat în criteriile maturizării ale lui Allport sub forma dezvoltării intereselor puternice în afara sinelui și participarea într-o sferă semnificativă de activitare umană. Din partea psihologiei dezvoltării, Neugarten vorbește despre manipulare și control al mediului, stăpânire și competență în dezvoltarea personalității adulte, în sensul că, la această vârstă, se presupune că individul reușește să îndeplinească o plajă complexă de activități - la locul de muncă, în familie și în sfera personală. Una dintre tendințele de bază ale vieții propuse de Bühler se referă la obiectivele de avansare în lume și modificarea ei în mod creativ, fie prin efort fizic ori mental. Birren și Renner includ, de asemenea, în criteriile sănătății mentale la vârsta adultă târzie, măsura în care individul profită de oportunitățile din mediu, iar aceasta atinge anumite aspecte ale stăpânirii mediului formulate și de Jahoda, care implică, în cea mai mare parte, abilitatea individului de a alege sau crea medii potrivite pentru propria condiție psihică. Luate la un loc, participarea activă și gestionarea mediului sunt elemente importante ale funcționării pozitive. În modelul lui Ryff, individul cu un nivel crescut al controlului mediului prezintă un sentiment de stăpânire și competență în gestionarea mediului, are control asupra unei game complexe de activități externe, știe să utilizeze eficient oportunitățile din jur și este capabil să aleagă sau să creeze contexte adecvate propriilor nevoi și valori, în timp ce un nivel scăzut implică dificultăți în gestionarea treburilor zilnice, sentimentul de incapabilitate de a schimba sau îmbunătăți contextul, neconștientizarea oportunităților din jur și lipsa sentimentului de control asupra lumii exterioare.

Scopul în viață apare în teoria lui Bühler sub forma scopului de a schimba lumea în mod creativ în perioada adultă, urmat apoi de scopul menținerii unei ordini interioare în următoarea etapă a vieții. Și în teoria lui Erikson există această intenție de integrare emoțională din ultimul stadiu de dezvoltare, intenție asemănătoare cu cea specificată de Bühler la bătrânețe. Rogers numește trăirea existențială crescută, dorința de a trăi fiecare moment din plin, a fi scopul persoanei pe deplin funcționale, iar Allport specifică, printre componentele centrale ale maturizării, existența unei filozofii unificatoare de viață, caracterizată de o înțelegere clară a scopului vieții, de un sens al 
direcției și de intenționalitate. Printre criteriile sănătăţii mentale ale lui Jahoda se numără și integrarea, care presupune o perspectivă unificatoare asupra vieții, ce conferă sentimentul că aceasta are un scop și un sens. Această perspectivă contribuie la sentimentul unității, echilibrului și integrării diferitelor părți ale sinelui. Și Birren și Renner vorbesc despre importanța integrării experiențelor de pe parcursul vieții într-un context semnificativ pentru perioada adultă târzie. Toate aceste perspective subliniază importanța unui scop în viață pentru starea de bine, prin sentimentele de semnificație și integrare pe care le determină obiectivele, intențiile și sentimentul de orientare. Ryff definește persoana cu un nivel crescut al acestei dimensiuni ca având scopuri în viață și sentimentul că are o direcție, simte că există sens în prezent și trecut, are credințe care îi conferă un scop vieții și are țeluri și obiective pentru a trăi. Scorul scăzut, pe de altă parte, implică lipsa sentimentului că are o direcție și că viața are un scop, puține obiective sau țeluri, neînțelegerea scopului trecutului propriu și lipsa convingerilor ori perspectivei care dă sens vieții.

Dezvoltarea personală prin dezvoltarea continuă a potențialului propriu este o altă abilitate necesară pentru starea de bine și pentru adaptarea la o lume într-o continuă schimbare. Rogers vorbește despre deschiderea spre experiență ca fiind una dintre caracteristicile persoanei pe deplin funcționale, iar aceasta implică o conștientizare crescută a lumii înconjurătoare și observarea lucrurilor din afara categoriilor preconcepute. De asemenea, profilul acestei persoane este în continuă dezvoltare și devenire, mai degrabă decât atingerea unei stări fixe în care toate problemele sunt rezolvate. Maslow vorbește despre auto-actualizare ca un proces continuu, iar această nevoie de actualizare și de a-și atinge propriul potențial se regăsește și în criteriile lui Jahoda privind sănătatea mentală. Și în tendințele de bază ale vieții prezentate de Bühler există această creștere continuă a individului, de la adaptarea auto-limitată la expansiune creativă și mai apoi la ordine interioară. De asemenea, etapele de dezvoltare ale lui Erikson sunt caracterizate de sarcini de evoluție pentru eu, iar în urma însumării acestor perspective, Ryff adaugă dezvoltarea personală ca ultimă dimensiune a modelului integrativ al stării de bine psihice și descrie individul cu un nivel înalt al dezvoltării personale ca fiind caracterizat de un sentiment de dezvoltare continuă, este deschis experiențelor noi, are abilitatea de a-și realiza potențialul, observă îmbunătățirile asupra sinelui și comportamentului de-a lungul timpului și se dezvoltă în feluri care reflectă mai multă cunoaștere de sine și eficacitate. La polul opus se află individul cu un sentiment de stagnare personală, lipsa sentimentului de îmbunătățire și dezvoltare în timp, incapacitatea de a dezvolta noi atitudini sau comportamente și plictiseală sau dezinteres față de viață.

Importanța relațiilor interpersonale de calitate este bine evidențiată în multe dintre teoriile de bază ale psihologiei, unde reprezintă un element foarte important ori chiar esențial pentru o dezvoltare sănătoasă și pentru atingerea bunăstării, începând $c u$ teoria ataşamentului a lui Bowlby, la piramida trebuințelor a lui Maslow, stadiile de dezvoltare propuse de Erikson sau individul pe deplin funcțional al lui Rogers. Campbell și colaboratorii (1976) arată că viața de familie, căsătoria și relațiile apropiate de prietenie au cel mai important rol în starea de bine subiectivă, iar Myers (1999) evidențiază nevoia umană de a apartenență și implicațiile ei asupra satisfacției cu viața. La Guardia și colaboratorii (2000) demonstrează că cei cu care individul se simte în siguranță sunt cei care facilitează sentimentele de autonomie, competență și conexiune. $\mathrm{Cu}$ alte cuvinte, atașamentele securizante favorizează starea de bine în cea mai mare parte datorită faptului că reprezintă relații în cadrul cărora sunt satisfăcute nevoile de autonomie, competență și asociere, conexiune. Astfel, literatura de specialitate demonstrează că nu cantitatea, ci calitatea relațiilor reprezintă elementul-cheie în predicția stării de bine psihologice (Nezlek, 2000).

\section{OBIECTIV ȘI IPOTEZE}

Datorită faptului că interacțiunile umane de calitate reprezintă un element de bază în spijinul stării de bine, iar obiceiurile din cadrul familiei promovează astfel de interacțiuni, acestea pot ajuta la scăderea stresului vieții cotidiene (Cheal, 1988; Yoon, Newkirk, \& Perry-Jenkins, 2015) și la creșterea calității percepute a vieții (Fiese et al., 2002), astfel că ne propunem ca obiectiv general al acestei cercetări să investigăm relația dintre obiceiurile din familie și starea de bine psihologică a individului. Mai specific, această lucrare urmărește să cerceteze efectele pe care aceste obiceiuri, implementate în familia de origine a individului, 
le au asupra celor șase dimensiuni ale stării de bine identificate de Ryff (1989a) - autoacceptare, relații pozitive cu ceilalți, autonomie, scop în viață, gestionarea mediului și creștere personală, de-a lungul timpului. În acest sens, vom investiga această relație cu ajutorul instrumentelor de măsurare ale celor două variabile, printr-un design de tip corelațional. Avem următoarele ipoteze:

Ipoteza 1: Există o corelație pozitivă între frecvența obiceiurilor familiale din familia de origine și starea de bine psihologică a individului.

Ipoteza 2: Există o corelație pozitivă între importanța obiceiurilor familiale din familia de origine și starea de bine psihologică a individului.

Ca obiective exploratorii, ne propunem să investigăm relația variabilelor cu datele socio- demografice, mai specific relația dintre vârstă, respectiv statut marital și starea de bine, dar și dintre reprezentarea retrospectivă a obiceiurilor și gen, respectiv statut marital.

\section{METODĂ}

\section{Participanți}

Eșantionul este format din 129 participanți cu vârste cuprinse între 18 și 71 de ani (F: 62.8\%), dintre care $47.28 \%$ adulți emergenți $(\mathrm{N}=61), 51.16 \%$ adulți $(\mathrm{N}=66)$ și $1.55 \%$ vârstnici $(\mathrm{N}=2)$. Numărul inițial al participanților era 131, însă doi au fost eliminați din cercetare din cauză că nu împliniseră vârsta de 18 ani. Majoritatea participanților au studii superioare (52.3\% licență; $12.3 \%$ masterat; $2.3 \%$ doctorat), pentru $31.3 \%$ ultimul nivel de studii absolvit este liceul, iar pentru o persoană - gimnaziul $(0.8 \%)$. Un procent de $69.5 \%$ din participanți sunt angajați, majoritatea cu venit lunar crescut (41.8\%), 28.7\% - mediu, iar restul $31 \%$ ( $8 \%$ venit scăzut; $23 \%$ neangajaţi). Privind starea civilă, $58.1 \%$ sunt necăsătoriți, $34.1 \%$ căsătoriți, iar $7.8 \%$ divorțaţi/văduvi.

\section{Instrumente}

\section{Family Routines Inventory (FRI)}

Family Routines Inventory (FRI) cuprinde $28 \mathrm{de}$ itemi care acoperă zece domenii și se referă la o plajă de rutine din viața de zi cu zi, importante pentru familie și pentru buna funcționare a acesteia, și încă 28 itemi pentru evaluarea importanței percepute. În cadrul acestui instrument, rutinele familiale sunt conceptualizate drept comportamente observabile și predictibile în care sunt implicați doi sau mai mulți membri ai familiei, cu frecvență zilnică sau săptămânală în viața familiei (Jensen et al., 1983). Avantajul principal al acestui instrument este compus din faptul că este relativ scurt și ușor de completat (Fiese et al., 2002).

În realizarea acestui instrument (Jensen et al., 1983) au fost identificate rutinele pozitive din familie care, prin furnizarea stabilității și continuităţii în perioade stresante și prin potențarea ideii de familie solidară și puternică, au factor protector împotriva sănătății precare. În dezvoltarea instrumentului s-a ținut cont de variabilele ce țin de background-ul familial, astfel încât s-a minimizat influența diferențelor interculturale și de statut.

Itemii sunt organizați în 10 domenii sau arii de funcționare a familiei, și anume: zile de muncă; sfârșit de săptămână și timp de relaxare; rutinele copiilor; rutinele părinților; ora de culcare; mese; familia extinsă; plecare și întoarcere acasă; rutine de disciplină; treburi casnice.

Instrumentul a fost conceput astfel încât să evalueze rutinizarea pe trei dimensiuni: acceptarea rutinei (măsura în care familia asumă un set de rutine comportamentale ca parte din activitățile zilnice), aderența la rutină (măsura în care familia adoptă rutinele pe care și le-a asumat) și importanța rutinei pentru familie.

Fiecare item prezintă o rutină, urmată de o întrebare prin intermediul căreia sunt determinte acceptarea și aderența acesteia de către familie ("Reprezenta asta o rutină la tine în familie?"), în timp ce importanța subiectivă este evaluată printr-o întrebare suplimentară („Cât de important era acest obicei pentru a păstra familia puternică?").

Respondenții au posibilitatea de a răspunde la prima întrebare pe o scală Likert în 4 puncte, de la „Întotdeauna - în fiecare zi“ la „Aproape niciodată“. Variantele de răspuns ale întrebării următoare indică importanța pe o scala Likert în 3 puncte, de la „Foarte important" la „Deloc important".

Family Routines Inventory este o scală sumativă. Astfel, vom calcula ponderea fiecărei rutine implementate în familie prin frecvența ei în familia respectivă, $\mathrm{cu}$,întotdeauna - aproape în fiecare $\mathrm{zi}^{\text {“ }}$ având valoarea 3 , „de $3-5$ ori pe săptămână“ $=2$, ,de 1-2 ori pe săptămână“ $=1$, iar ,aproape niciodată“" 0 . Valorile posibile ale scorului total variază între 0 
şi 84. Scorul pentru importanţă implică acelaşi raţionament ca în metoda anterioară. Deci, scorul fiecărei rutine este determinat astfel: „foarte important" $=3$; „oarecum important ${ }^{\prime \prime}=2$; „deloc important $"=1$. În acest mod, se poate calcula un scor al importanței care ponderează rutinele existente în familie prin gradul de importanță individuală pentru „menținerea familiei puternice“. Și în acest caz, scorurile pot avea valori între 0 și 84 (Jensen et al., 1983).

\section{Ryff's Psychological Well-Being Scale (RPWB)}

Ryff Psychological Well-Being Scale cuprinde 84 de itemi clasificați pe 6 dimensiuni: evaluări pozitive despre sine și despre propriul trecut (auto-acceptare); relații pozitive și de calitate cu ceilalți (relații pozitive $c u$ ceilalți); un sentiment de auto-determinare, independență și libertate față de norme (autonomie); posedarea unor țeluri în viață și credința că propria existență are sens (scop în viață); abilitatea de a gestiona cu succes viața și mediul din jur (stăpânirea mediului); continua creștere și dezvoltare și deschidere spre experiențe noi (creștere personală) (Springer \& Hauser, 2006). Pentru că necesită mai puține resurse (efort cognitiv, timp), astfel fiind mai ușor de completat, am optat pentru varianta scurtă a acestei scale. Aceasta necesită doar jumătate din timpul de completare a RPWBS, având un total de 42 de itemi, și este tradusă și validată pe populația din România (Kállay, \& Rus, 2014).

Criteriul de selectare a celor 6 dimensiuni componente a fost frecvența apariției acestora în literatura de specialitate de până atunci, rezultând astfel un model integrativ care surprinde cele mai recurente aspecte ale funcționării pozitive din literatura care tratează dezvoltarea de-a lungul vieții, creșterea personală și sănătătatea mintală (Ryff, 1989a).

Varianta scurtă a scalei RPWB conține câte 7 itemi pentru fiecare dimensiune, la care utilizatorii au posibilitatea de a răspunde pe o scală Likert în 7 trepte, de la „Acord total“ la „Dezacord total“.

Prima dimensiune a instrumentului, autonomie, se referă atât la autonomia funcțională a individului, cât și la un locus al controlului intern îmbinat cu abilitatea de a rezista presiunii sociale de a gândi și de a acționa într-un anume fel (Ryff, 1989a). Aceasta conține itemi precum „Nu îmi este teamă să îmi exprim opiniile, chiar și atunci când sunt în opoziție cu opiniile majorității oamenilor“; „, Mă preocupă adesea ce cred oamenii despre mine" și înglobează auto- determinarea, independența și reglarea comportamentului din interior (Ryff, 1989a).

Perspectivele integrate privind controlul mediului compun înțelesul acestei dimensiuni drept participarea activă în gestionarea mediului pentru a fi potrivit pentru condiția psihică a individului și cuprinde itemi ca „Solicitările de zi cu zi mă descurajează des“; „Simt că nu mă potrivesc cu oamenii și comunitatea din jurul meu“; „Am o locuință și un stil de viață care îmi plac".

Dezvoltarea optimă necesită, pe lângă o serie de calități dobândite, și dezvoltarea, creșterea continuă a propriului potențial și a individului ca persoană, aspecte indispensabile adaptării la mediul care este într-o continuă schimbare (Ryff, 1989a). Creșterea personală cuprinde itemi care evaluează acestă continuă dezvoltare prin itemi precum „Cred că este important să ai experiențe noi, care să provoace felul în care gândești despre tine și despre lume“, „, Mi se pare că m-am dezvoltat mult ca persoană de-a lungul timpului“.

Importanța relațiilor interpersonale pozitive, calde și de încredere este, de asemenea, menționată des în teoriile privind funcționarea pozitivă, astfel că abilitatea de a dobândi relații pozitive cu ceilalți este evaluată prin itemi ca „Adesea, mă simt singur(ă) deoarece am puțini prieteni apropiați cu care să-mi împărtășesc problemele“; „Știu că pot avea încredere în prietenii mei și ei știu că pot avea încredere în mine“; „Îmi fac plăcere discuțiile personale cu membrii familiei mele sau cu prietenii“ (Ryff, 1989a).

Scopul în viață apare în literatură ca o componentă indispensabilă a stării de bine, astfel încât un individ care funcționează pozitiv are scopuri, intenții și un sentiment al direcției în viață. Toate aceste elemente clădesc un sentiment de includere a diferitelor părți ale propriei vieți și de construire a unui sens al acesteia (Ryff, 1989a). Evaluarea acestei dimensiuni se realizează prin itemi precum „Activitățile mele de zi cu zi îmi par adesea banale și nesemnificative“; „, Nu îmi dau foarte bine seama care sunt obiectivele mele în viață“; „Uneori, simt că nu mai am nimic de făcut în viață“".

Ultima dimensiune, autoacceptarea, este elementul cel mai recurent din literatura ce studiază funcționarea pozitivă, astfel încât atitudinea pozitivă despre sine şi propria viață este criteriul central al stării de bine (Ryff, 1989a), iar câteva exemple de itemi 
incluși sunt „Când mă uit la povestea vieții mele, sunt mulțumit(ă) de modul în care s-au așezat lucrurile“; „Îmi plac multe aspecte ale personalității mele“; , Din multe puncte de vedere, sunt dezamăgit(ă) de ceea ce am realizat până acum“.

Conform Ryff \& Keyes (1995), există diferențe de vârstă, astfel: la dimensiunile scop în viață și creștere personală, persoanele mai tinere vor avea scoruri semnificativ mai mari comparativ cu cei mai în vârstă respondenți, iar în cazul gestionării mediului și relațiilor pozitive există creșteri odată cu vârsta, fenomen întâlnit și în cazul autonomiei, unde, spre deosebire de celelalte cazuri, creșterile au loc de la perioada adultă emergentă până la perioada adultă de mijloc. Privind diferențele de sex, acestea au fost semnificative doar în cazul domeniului relații pozitive, unde femeile au scoruri mai ridicate decât bărbații.

Scala este sumativă, iar itemii vor fi adunaţi pentru obținerea scorului pe dimensiuni, cu valori de la 1 ("Total dezacord“, sau „Acord total“, pentru itemii inversați) la 7 (“Acord total", sau „Total dezacord“" pentru itemii inversați).

\section{Design}

În cadrul acestei cercetări am optat pentru un design de tip cantitativ, descriptiv, corelațional și transversal, având ca variabilă independentă obiceiurile familiale, operaționalizate sub forma frecvenței și importanței percepute ale acestor obiceiuri din cadrul familiei de origine, iar ca variabilă dependentă
- starea de bine psihologică, compusă din cele șase dimensiuni ale modelului lui Ryff (1989a): autonomie, controlul mediului, relații pozitive cu ceilalți, scop în viață, dezvoltare personală și autoacceptare.

\section{Procedură}

Am recrutat participanții pe bază de voluntariat, distribuind scalele online cunoștințelor, iar acestea, la rândul lor, distribuindu-le mai departe. Participanții au fost informați despre faptul că studiul investighează obiceiurile familiale și starea de bine. De asemenea, confidențialitatea datelor a fost asigurată, iar prima secțiune a formularului, consimțământul informat privind participarea în cercetare, a trebuit semnată înainte de începerea completării scalelor. Participanții au primit o secțiune instrucțională privind fiecare scală, înainte de completare.

\section{REZULTATE}

Pentru testarea obiectivului acestei cercetări, anume existența unei corelații pozitive între obiceiurile familiale și starea de bine, a fost utilizat coeficientul de corelație Pearson. Conceptul de obiceiuri familiale a fost structurat pe două dimensiuni: frecvență și importanță, în timp ce starea de bine a fost împărțită în șase domenii: autonomie, controlul mediului, dezvoltare personală, relații pozitive cu ceilalți, scop în viață şi autoacceptare. Tabelul 1 prezintă matricea de corelații dintre variabilele incluse în studiu.

\begin{tabular}{|c|c|c|c|c|c|c|c|c|}
\hline & 1 & 2 & 3 & 4 & 5 & 6 & 7 & 8 \\
\hline 1. FRI fr & \multicolumn{8}{|c|}{ - } \\
\hline 2. FRI imp & $.665^{* *}$ & - & & & & & & \\
\hline 3. Autonomie & $.210^{*}$ & .180 & - & & & & & \\
\hline 4. Control & $.401 * *$ & $.341 * *$ & $.365 * *$ & - & & & & \\
\hline 5. Dezvoltare & .163 & .117 & $.472 * *$ & $.388 * *$ & - & & & \\
\hline 6. Relații & $.315^{* *}$ & .177 & $.338 * *$ & $.544 * *$ & $.530 * *$ & - & & \\
\hline 7. Scop & $.322 * *$ & $.287 * *$ & $.379 * *$ & $.629 * *$ & $.632 * *$ & $.612 * *$ & - & \\
\hline 8. Autoacc & $.349 * *$ & $.214^{*}$ & $.527^{* *}$ & $.639^{* *}$ & $.627^{* *}$ & $.624 * *$ & $.730 * *$ & - \\
\hline
\end{tabular}

Tabel 1. Matricea de corelații dintre variabile 
Note: ${ }^{\star} \mathrm{p}<.05,{ }^{\star *} \mathrm{p}<.01, \mathrm{FRI}$ fr $=$ frecvența obiceiurilor; FRI imp = importanța obiceiurilor; Control = controlul mediului; Dezvoltare $=$ dezvoltare personală; Relații = relații pozitive cu ceilalți; Scop = scop în viață; Autoacc $=$ autoacceptare.

În concordanță cu ipoteza 1 , am identificat o corelație pozitivă între frecvența obiceiurilor familiale și următoarele domenii ale stării de bine: autonomie $(\mathrm{r}=0.21)$, controlul mediului $(\mathrm{r}=0.41)$, relații pozitive cu ceilalți $(r=0.31)$, scop în viață $(r=0.32)$ și autoacceptare $(r=0.34)$. Majoritatea corelațiilor identificate sunt medii (Cohen, 1988), excepție fãcând autonomia, care are o corelație mică spre medie. Și cea de-a doua ipoteză a fost confirmată: există o corelaţie pozitivă medie a importanței obiceiurilor familiale cu controlul mediului ( $r=0.34)$, medie spre mică cu scopul în viață $(r=0.28)$ și mică în cazul autoacceptării $(r=0.21)$. Am identificat o corelaţie mică nesemnificativă din cauza lipsei anumitor date între importanța obiceiurilor familiale și relațiile pozitive cu ceilalți $(\mathrm{r}=0.17)$, astfel că am optat pentru o analiză retrospectivă a puterii statistice pentru a vedea la ce volum al eșantionului această corelație ar fi devenit semnificativă statistic. În urma acesteia am observat că numărul necesar de răspunsuri ar fi fost 125, în timp ce am primit doar 103. La fel și în cazul relației dintre frecvența obiceiurilor și dezvoltarea personală $(r=0.16)$, unde am fi avut nevoie de aproximativ 150 de subiecți.

\section{Obiective exploratorii}

\section{Corelate socio-demografice ale stării de bine}

Pentru investigarea primului obiectiv exploratoriu, și anume relația dintre corelatele socio- demografice și starea de bine, am utilizat coeficientul de corelație Pearson cu scopul de a identifica o corelație între vârstă și starea de bine. Matricea de corelații este prezentată în tabelul

2. Dintre toate domeniile stării de bine, există o corelație medie (Cohen, 1988) între controlul mediului și vârstă $(r=0.32)$.

\begin{tabular}{l|cccccc}
\hline & Autonomie & Control & Dezvoltare & Relații & Scop & Autoacceptare \\
\hline Vârstă & -.104 & $.324^{* *}$ & -.132 & .161 & .170 & .032 \\
\hline
\end{tabular}

Tabel 2. Corelații între vârsta și starea de bine

Note: ${ }^{* *} \mathrm{p}<.01$; Control $=$ controlul mediului; Dezvoltare $=$ dezvoltare personală; Relații $=$ relații pozitive cu ceilalți; Scop = scop în viață.

Privind statutul marital, am folosit ANOVA pentru categoriile „Necăsătorit“, „Căsătorit" și „Divorțat/Văduv“ și am identificat diferențe semnificative între acestea $(F=7.67)$. Testul ANOVA arată că cel puțin într-o pereche dintre grupe există o diferență, dar nu specifică unde, prin urmare am utilizat testul post-hoc Scheffe. Astfel, am găsit o diferență semnificativă la controlul mediului între cei căsătoriți $(\mathrm{N}=43, \mathrm{~m}=35.6)$ și necăsătoriți $(\mathrm{N}=74, \mathrm{~m}=32.09), \mathrm{cu}$ $\mathrm{p}=0.001$.

\begin{tabular}{|c|c|c|c|c|c|}
\hline \multirow{2}{*}{ Domeniu } & Statut marital & Media & DevSt & $F$ & $p$ \\
\hline \multirow{3}{*}{ Controlul mediului } & Necăsătorit* & 32.09 & 5.38 & \\
\cline { 2 - 5 } & Căsătorit* & 35.60 & 4.98 & 7.67 & .001 \\
\cline { 2 - 5 } & Divorțat/Văduv & 36.90 & 7.17 & & \\
\hline
\end{tabular}

Tabel 3. Statut marital și starea de bine 


\section{Corelate socio-demografice ale obiceiurilor}

Cu scopul de a vedea dacă există diferențe în reprezentarea retrospectivă a obiceiurilor familiale am utilizat testul t. În urma comparației frecvenței între femei $(\mathrm{N}=68, \mathrm{~m}=50.7)$ și bărbați $(\mathrm{N}=39, \mathrm{~m}=45.2)$ a fost identificată o diferență semnificativă a perceperii frecvenței obiceiurilor, cu scorurile femeilor mai ridicate, astfel $\mathrm{t}(105)=2.11, \mathrm{p}=0.036$. De asemenea, și în cazul importanței există diferențe semnificative, $\mathrm{t}(102)=3.29, \mathrm{p}=0.001$, cu fetele $(\mathrm{N}=66, \mathrm{~m}=62.5)$ având scoruri mai mari decât băieții $(\mathrm{N}=38, \mathrm{~m}=55.23)$. Rezultatele sunt prezentate în tabelul 4.

\begin{tabular}{|l|c|c|c|c|c|c|}
\hline & Gen & Medie & DevSt & $t$ & $d f$ & $p$ \\
\hline \multirow{2}{*}{ FRI frecvență } & $\mathrm{F}$ & 50.70 & 13.88 & 2.11 & 105 & .036 \\
& $\mathrm{M}$ & 45.20 & 11.02 & & \\
\hline FRI importanță & $\mathrm{F}$ & 62.50 & 11.05 & 3.29 & 102 & .001 \\
\hline
\end{tabular}

Tabel 4. Genul și reprezentarea frecvenței și importanței obiceiurilor

Note: $\mathrm{F}=$ feminin; $\mathrm{M}=$ masculin.

Privind statutul marital și reprezentarea obiceiurilor, am dorit să observăm dacă există diferențe între grupe. ANOVA a indicat o diferență semnificativă ( $F=7.34)$ în cazul importanței percepute a obiceiurilor, iar testul post-hoc Scheffe a relevant că diferența există între cei necăsătoriți $(\mathrm{N}=62, \mathrm{~m}=56.54)$ și cei căsătoriți $(\mathrm{N}=34, \mathrm{~m}=64.44)$, cu p=0.001.

\begin{tabular}{|l|l|c|c|c|c|}
\hline \multirow{4}{*}{ FRI fr } & \multicolumn{1}{|c|}{ Statut } & Medie & DevSt & $F$ & $p$ \\
\hline \multirow{5}{*}{ FRI imp } & Necăsătorit & 46.90 & 12.82 & & \multirow{2}{*}{.159} \\
\cline { 2 - 6 } & Căsătorit & 52.23 & 13.35 & 1.87 & \\
\cline { 2 - 6 } & Divorțat/Văduv & 48.25 & 13.24 & & \\
\cline { 2 - 6 } & Necăsătorit* & 56.54 & 10.42 & & .001 \\
\cline { 2 - 6 } & Căsătorit* & 64.44 & 11.43 & 7.34 & \\
\cline { 2 - 6 } & Divorțat/Văduv & 65.87 & 9.47 & & \\
\hline
\end{tabular}

Tabel 5. Statutul marital și reprezentarea frecvenței și importanței obiceiurilor

Note: FRI fr = frecvența obiceiurilor; FRI imp = importanța obiceiurilor.

\section{DISCUȚII}

Scopul acestui studiu a fost de a investiga dacă existența anumitor rutine și ritualuri în familia de origine este legată de bunăstarea psihologică a individului. Ipotezele ne-au fost confirmate, în concordanță cu literatura de specialitate (ex. Fiese, \& Kleine, 1993;
Boyce et al., 1997): am identificat o corelație pozitivă medie a frecvenței și importanței obiceiurilor cu starea de bine psihologică. Această corelație implică faptul că interacțiunile de calitate, cu un nivel crescut de profunzime a sensului, din cadrul familial din care provine individul, au un rol asupra bunăstării ulterioare. 
Mai specific, cu cât frecvența percepută a obiceiurilor familiale este mai pronunțată, cu atât individul va prezenta scoruri mai înalte ale stării de bine privind capacitatea de gestionare a mediului în funcție de propriile nevoi și preferințe, autoacceptarea, autonomia, relațiile de calitate cu cei din jur și scopul în viață. Această primă concluzie explică cum, în baza obiceiurilor implementate în familia de origine, care conferă o structură vieții de familie şi activităților din cadrul acestui context, individul reușește să dezvolte o capacitate crescută de control al mediului, având modelul din copilărie. Totodată, va fi mai orientat către scopuri, iar acest lucru poate fi explicat de natura obiceiurilor care, pe lângă scopuri instrumentale, capătă sensuri transcendentale. În plus, va dobândi sentimentul că există un sens în prezent și trecut, că există o continuitate căreia îi poate da un înțeles. Cercetările anterioare arată că aceste obiceiuri promovează valori culturale precum independența și apartenența la grup (Martini, 1996; Blum- Kulka, 2012), iar astfel se explică și legătura cu autonomia crescând într-un astfel de context, individul învață să fie mai auto-determinat și mai independent. Având în vedere natura interactiunilor din cadrul acestor rutine și ritualuri, dar și natura relațiilor din cadrul familiei, relații intime, bazate pe încredere, acceptare și iubire necondiționată, individul este ajutat să dezvolte o atitudine mai pozitivă față de sine, dar și să relaționeze cu ceilalți într-un mod mai sănătos, mai autentic și la un nivel mai profund.

Corelația dintre importanța obiceiurilor și starea de bine în controlul mediului, scop în viață și autoacceptare, poate semnifica faptul că reprezentarea retrospectivă a importanței obiceiurilor din cadrul familiei de origine influențează predominant partea afectivă, mai profundă a bunăstării psihologice, mai specific contribuie la sentimentul de direcție, de orientare către ceva mai măreț, care să trezească sentimentul de căldură, structură și siguranță asigurate de cadrul familial și de interpretarea rolurilor prestabilite din contextele create în jurul acestor obiceiuri. De asemenea, autoacceptarea este promovată de reprezentarea importanței rutinelor și ritualurilor, astfel, cu cât acestea sunt percepute ca fiind mai importante de către individ, $\mathrm{cu}$ atât nivelul de autoacceptare este mai crescut, întrucât în acest cadru se promovează acceptarea necondiționată a membrilor grupului.
Obiectivele exploratorii ne-au relevat următoarele aspecte: există o corelație medie între vârstă și controlul mediului. Cu alte cuvinte, odată cu creșterea vârstei, starea de bine psihologică privind controlul mediului este mai ridicată - individul dezvoltă sentimentul de control crescut odată cu habituarea cu sarcinile aferente perioadei adulte și rutinizarea responsabilităţilor. Acest rezultat este concordant cu literatura de specialitate (Ryff, \& Singer, 2006), însă, conform studiilor anterioare, era de așteptat să existe o astfel de corelație și cu autonomia. Surprinzător, în urma analizei datelor, am identificat o corelație negativă, dar nesemnificativă statistic, între vârstă și acest domeniu al stării de bine. Având în vedere natura post-comunistă a societății românești, în acest cadru cultural s-a promovat conformismul social pentru o vreme îndelungată, dar și recentă. Indivizii din această societate sunt încă împovărați de grija părerilor și aşteptărilor altora despre propriile acțiuni și se conformează, în majoritatea cazurilor, presiunilor sociale, fără a pune la îndoială corectitudinea și discernământul din spatele acțiunilor, fiindcă așa au fost educați.

Privind statutul marital și starea de bine, singura diferență semnificativă identificată este între cei căsătoriți și cei necăsătoriți pe domeniul „controlul mediului“. Scorul mai scăzut al celor necăsătoriți poate fi explicat de faptul că implicațiile vieții de familie promovează necesitatea și dezvoltarea unui mediu mai structurat, care vine natural și progresiv odată cu această etapă, iar astfel sentimentul de control perceput crește odată cu habituarea cu acest mediu mai organizat. De asemenea, impactul crescut al propriului punct de vedere în luarea deciziilor de familie contribuie, probabil, la acest sentiment de control. În aceeași notă, putem presupune că, din cauza lipsei a ceva concret de controlat, cei necăsătoriți se simt mai incompetenți în acest sens, iar cei căsătoriți se autoevaluează mai în control.

Reprezentarea retrospectivă a obiceiurilor din familia de origine ca fiind mai importante și mai frecvente la femei decât la bărbați poate fi datorată diferențelor de gen privind exprimarea emoțiilor. Chiar din perioada postnatală, sugarii diferă în funcție de gen în frecvența în care își exprimă emoțiile, iar acest aspect influențează felul în care ceilalți le răspund și se raportează la ei (Izard, 1991). Mai departe, aceste lucruri ajung să devină întăriri pentru stilul de exprimare pe 
care și-l dezvoltă și, implicit, pentru formarea personalității. Deci, atât timp cât răspunsul părinților către copil se bazează pe genul acestuia, fiecare sex va dezvolta stiluri de exprimare diferite. În adiție, studiile arată că utilizarea termenilor emoționali de către părinți diferă în funcție de sexul copilului, în cazul fetelor fiind mai variați și mai frecvenți decât la băieți (Adams, Kuebli, Boyle, \& Fivush, 1995). Cercetarea întocmită de Fivush (1995) aduce un alt argument relevant pentru rezultatul obținut în cadrul studiului nostru: în copilărie, mamele tind să se focuseze pe emoțiile pozitive în conversațiile cu fiicele lor și să nu discute despre furie cu acestea, în timp ce, cu băieții, emoțiile negative și cele pozitive sunt discutate în egală măsură. De asemenea, conversația cu fetele se axează pe starea emoțională în sine, dar cu băieții, de obicei, se discută cauzele și consecințele emoțiilor. Mai mult, femeile raportează că trăiesc, exprimă și valorifică emoțiile mai mult decât o fac bărbații (Allen, \& Hamsher, 1974; Allen, \& Haccoun, 1976; Sprecher, \& Sedikides, 1993). Astfel, putem explica rezultatul cercetării privind reprezentarea importanței și frecvenței în baza acestor diferențe de socializare, exprimare și trăire emoțională - fetele sunt învățate să valorifice mai mult partea afectivă a lucrurilor și să le vadă într-o lumină mai favorabilă, în timp ce băieții sunt obișnuiți să pună accent pe partea practică, astfel că ajung să își reprezinte în moduri diferite aceste obiceiuri, întrucât partea afectivă este activată în măsuri diferite.

Implicarea crescută și frecventă în organizarea acestor rutine și ritualuri este mai recentă pentru indivizii căsătoriți, spre deosebire de cei necăsătoriți, care nu au mai luat parte regulat la astfel de obiceiuri din prima parte a vieții. Pregătirea lor, dar și participarea, implică gestionarea relațiilor apropiate și a legăturilor de familie, deci există o legătură afectivă puternică și clară. Aceste elemente pot explica importanța percepută mai crescută a acestor obiceiuri pentru cei căsătoriți, spre deosebire de cei necăsătoriți. De altfel, cum natura acestor interacțiuni este de a promova sentimentele de apartenență și securitate, nevoia de afiliere este satisfăcută într-o mai mare măsură de intimitatea și apropierea din cadrul acestora (Crespo et al., 2008). Iar cu cât indivizii au parte de interacțiuni mai durabile, puternice și divese, cu atât este mai probabil ca aceștia să le acorde o semnificație mai profundă (Fiese et al., 2002).
O astfel de cercetarea schimbă focusul de pe individ pe întregul proces familial, iar aceasta este o perspectivă care reușește să identifice anumite aspecte într-un context mai complet. Obiceiurile din cadrul familiei sunt chiar la intersecția dintre factorii individuali și cei familiali, iar acest fapt poate oferi o perspectivă unică asupra modului în care viața de familie poate afecta adaptarea individului și caracteristicile și perspectivele individuale pot afecta funcționarea familie (Fiese et al., 2002).

Privind limitele pe care le prezintă acest studiu, în primul rând este vorba de încrederea în auto- raportare la scala Family Routines Inventory. Întrucât participanții au vârste cuprinse între 18 și 71 de ani, iar întrebările scalei fac referire la familia de origine, există o posibilitate crescută ca auto-raportările să nu fie tocmai exacte. Am dorit să observăm dacă există această asociere pe termen lung, însă, pentru răspunsuri mai acurate, viitoarele cercetări ar putea face referire la familia actuală, ori ar putea include subiecți cu o limită de vârstă impusă. $\mathrm{O}$ altă limitare o reprezintă lipsa considerării situației familiale, mai specific dacă familia de origine este biparentală sau nu. Ar fi fost interesant de observat dacă există diferențe între aceste grupe, având în vedere faptul că aceste obiceiuri au rol protector pentru copil în fața riscurilor asociate cu creșterea în familii netradiționale (Brody, Flor, 1997).

Această cercetare aduce o contribuție originală în literatura de specialitate în primul rând prin investigarea relației dintre aceste variabile în cadrul cultural românesc. $\mathrm{Cu}$ toate că rutinele și ritualurile familiale sunt încorporate în contextul cultural și ecologic al vieții de familie, una dintre slăbiciunile studierii lor este gama limitată a grupurilor etnice studiate. Întrucât există diferențe ale proceselor și conținutului obiceiurilor familiale între diferite culturi, este importantă această diversificare a cercetării tocmai pentru a observa mai clar natura și semnificația acestor diferențe. Nu doar că este dezirabil, ci este chiar esential ca studiul obiceiurilor familiale să se extindă din punct de vedere al plajei etnice, pentru o înțelegere mai complexă și, totodată, mai specifică a ceea ce implică aceste obiceiuri. De asemenea, sunt necesare mai multe studii longitudinale, deoarece sunt foarte puține în acest domeniu de cercetare (ex. Crespo et al., 2011), pentru a observa atât căror rutine li se aplică procesul tranzițional către ritualuri și invers, cât și efectele lor 
directe și indirecte asupra funcționării și bunăstării. În plus, $o$ abordare mai completă asupra lor este necesară, deoarece focusul majorității studiilor este asupra părților pozitive ale obiceiurilor familiale, în timp ce există și implicații negative adesea ignorate, precum stresul asociat (Evans, \& Rodger, 2008).

\section{CONCLUZII}

Obiectivul principal al acestui studiu a fost de a investiga dacă reprezentarea retrospectivă a frecvenței și importanței obiceiurilor din familia de origine va corela cu starea de bine psihologică a individului în contextul cultural românesc. Pornind de la cercetările anterioare asupra relației dintre aceste variabile și de la premiza că, dacă în cazurile clinice aceste obiceiuri au rol protector (Hauser et al., 1990; Dickstein et al., 1999; Manczak, Williams, \& Chen, 2017), iar în familiile cu cazuri speciale promovează o calitate percepută crescută a vieții (Schlebusch, Samuels, \& Dada, 2016), atunci este probabil ca și în cazurile nonclinice să promoveze bunăstarea, ipotezele ne-au fost confirmate: există o corelație pozitivă medie între obiceiurile din familie și starea de bine psihologică.

Pe lângă obiectivul ghidat de ipoteze, studiul de față a relevat și o corelație medie între vârstă și starea de bine psihologică pe domeniul controlul mediului, dar și o diferență pe același domeniu între cei căsătoriți - cu scoruri mai mari - și cei necăsătoriți. De altfel, am identificat diferențe în reprezentarea retrospectivă a obiceiurilor din familia de origine între femei și bărbați, femeile percepându-le ca fiind mai importante, dar și mai frecvente. Tot mai importante sunt văzute și de cei căsătoriți, comparativ cu cei necăsătoriți, însă frecvența percepută nu prezintă diferențe semnificative.

Aceste obiceiuri au rolul de organizatori ai vieții de familie din timpuri vechi, susținând stabilitatea grupului în perioade de stres ori tranziție și promovând adaptarea de-a lungul timpului. În zilele noastre, însă, menținerea acestor obiceiuri este dificilă din cauza cerințelor crescute din mediul extern și fragmentarea tot mai deasă a familiilor moderne. Prin această cercetare dorim să încurajăm familiile să desfăşoare în continuare obiceiurile potrivite pentru ele, să le adapteze pe cele care nu mai aduc rezultate pozitive și să dezvolte unele noi, adaptate vremurilor contemporane, întrucât au un aport relevant pentru buna funcționare familială și individuală.

\section{Bibliografie}

Airaksinen, T. (2002). The philosophy of the Marquis de Sade. Routledge.

Allen, J. G., \& Haccoun, D. M. (1976). Sex differences in emotionality: A multidimensional approach. Human Relations, 29(8), 711-722.

Allen, J. G., \& Hamsher, J. H. (1974). The development and validation of a test of emotional styles. Journal of Consulting and Clinical Psychology, 42(5), 663.

Andrews, F. M., \& Withey, S. B. (2012). Social indicators of well-being: Americans' perceptions of life quality. Springer Science \& Business Media.

Barton, A. W., Brody, G. H., Yu, T., Kogan, S. M., Chen, E., \& Ehrlich, K. B. (2019). The Profundity of the Everyday: Family Routines in Adolescence Predict Development in Young Adulthood. Journal of Adolescent Health, 64(3), 340-346.

Baxter, L. A., \& Braithwaite, D. O. (2006). Rituals as communication constituting families. In

L. Turner \& R. West (Eds.), The family communication sourcebook. (pp. 259-280). Thousand Oaks, CA: Sage.

Bennett, L. A., Wolin, S. J., \& McAvity, K. J. (1988). Family identity, ritual, and myth: A cultural perspective on life cycle transitions. Family transitions: Continuity and change over the life cycle, 211-234.

Bennett, L. A., Wolin, S. J., Reiss, D., \& Teitelbaum, M. A. (1987). Couples at risk for transmission of alcoholism: Protective influences. Family Process, 26(1), 111-129.

Blum-Kulka, S. (2012). Dinner talk: Cultural patterns of sociability and socialization in family discourse. Routledge.

Bossard, J. H., \& Boll, E. S. (1950). Ritual in family living.

Boyce, W. T., Jensen, E. W., Cassel, J. C., Collier, A. M., Smith, A. H., \& Ramey, C. T. (1977). Influence of life events and family routines on childhood respiratory tract illness. Pediatrics, 60(4), 609-615.

Boyce, W. T., Jensen, E. W., James, S. A., \& Peacock, J. L. (1983). The family routines inventory: Theoretical origins. Social Science \& Medicine, 17(4), 193-200.

Braithwaite, D. O., Baxter, L. A., \& Harper, A. M. (1998). The role of rituals in the management of the dialectical tension of "old" and "new" in blended families. Communication Studies, 49(2), 101-120.

Brody, G. H., \& Flor, D. L. (1997). Maternal psychological functioning, family processes, and child adjustment in rural, single-parent, African American families. Developmental psychology, 33(6), 1000.

Campbell, A., Converse, P. E., \& Rodgers, W. L. (1976). The quality of American life: Perceptions, evaluations, and satisfactions. Russell Sage Foundation.

Cheal, D. (1988). The ritualization of family ties. American Behavioral Scientist, 31(6), 632-643. 
Cohen, J. (1988). Statistical power analysis for the behaviors science.(2nd). New Jersey: Laurence Erlbaum Associates, Publishers, Hillsdale.

Compañ, E., Moreno, J., Ruiz, M. T., \& Pascual, E. (2002). Doing things together: Adolescent health and family rituals. Journal of Epidemiology \& Community Health, 56(2), 89-94.

Crespo, C., Davide, I. N., Costa, M. E., \& Fletcher, G. J. (2008). Family rituals in married couples: Links with attachment, relationship quality, and closeness. Personal Relationships, 15(2), 191-203.

Crespo, C., Kielpikowski, M., Pryor, J., \& Jose, P. E. (2011). Family rituals in New Zealand families: Links to family cohesion and adolescents' well-being. Journal of Family Psychology, 25(2), 184.

Curran, D., \& Curran, D. (1984). Traits of a healthy family. Ballantine Books.

Dickstein, S., St. Andre, M., Sameroff, A., Seifer, R., \& Schiller, M. (1999). Maternal depression, family functioning, and child outcomes: A narrative assessment. Monographs of the society for research in child development, 84-104.

Diener, E. (2000). Subjective well-being: The science of happiness and a proposal for a national index. American Psychologist, 55(1), 34-43.

Diener, E., \& Lucas, R. E. (1999). 11 personality and subjective well-being. Well-being: Foundations of hedonic psychology, 213.

Diener, E., Sapyta, J. J., \& Suh, E. (1998). Subjective well-being is essential to well- being. Psychological inquiry, 9(1), 33-37.

Eisenberg, M. E., Olson, R. E., Neumark-Sztainer, D., Story, M., \& Bearinger, L. H. (2004). Correlations between family meals and psychosocial well-being among adolescents. Archives of pediatrics \& adolescent medicine, 158(8), 792-796.

Erikson, E. H. (1966). D. ontogeny of ritualization: Ontogeny of ritualization in man. Philosophical Transactions of the Royal Society of London. Series B, Biological Sciences, 251(772), 337-349.

Evans, J., \& Rodger, S. (2008). Mealtimes and bedtimes: Windows to family routines and rituals. Journal of Occupational Science, 15(2), 98-104.

Fiese, B. H. (1992). Dimensions of family rituals across two generations: Relation to adolescent identity. Family process, 31(2), 151-162.

Fiese, B. H., \& Kline, C. A. (1993). Development of the Family Ritual Questionnaire: Initial reliability and validation studies. Journal of family psychology, 6(3), 290.

Fiese, B. H., \& Wamboldt, F. S. (2000). Family routines, rituals, and asthma management: A proposal for family-based strategies to increase treatment adherence. Families, Systems, \& Health, 18(4), 405.

Fiese, B. H., Foley, K. P., \& Spagnola, M. (2006). Routine and ritual elements in family mealtimes: Contexts for child well-being and family identity. New directions for child and adolescent development, 2006(111), 67-89.

Fiese, B. H., Hooker, K. A., Kotary, L., \& Schwagler, J. (1993). Family rituals in the early stages of parenthood. Journal of Marriage and the Family, 633-642.
Fiese, B. H., Tomcho, T. J., Douglas, M., Josephs, K., Poltrock, S., \& Baker, T. (2002). A review of 50 years of research on naturally occurring family routines and rituals: Cause for celebration?. Journal of family psychology, 16(4), 381.

Fulkerson, J. A., Story, M., Mellin, A., Leffert, N., Neumark-Sztainer, D., \& French, S. A. (2006). Family dinner meal frequency and adolescent development: Relationships with developmental assets and high-risk behaviors. Journal of Adolescent Health, 39(3), 337-345.

Greene Bush, E., \& Pargament, K. I. (1997). Family coping with chronic pain. Families, Systems, \& Health, 15(2), 147.

Grusec, J. E., \& Lytton, H. (1988). Socialization and the family. In Social Development (pp. 161- 212). Springer, New York, NY.

Guidubaldi, J., Cleminshaw, H. K., Perry, J. D., Nastasi, B. K., \& Lightel, J. (1986). The role of selected family environment factors in children's post-divorce adjustment. Family Relations: An Interdisciplinary Journal of Applied Family Studies.

Hauser, S. T., Jacobson, A. M., Lavori, P., Wolfsdorf, J. I., Herskowitz, R. D., Milley, J. E., ... \& Stein, J. (1990). Adherence among children and adolescents with insulin-dependent diabetes mellitus over a four-year longitudinal follow-up: II. Immediate and long-term linkages with the family milieu. Journal of Pediatric Psychology, 15(4), 527-542.

Henry, C. S., \& Lovelace, S. G. (1995). Family resources and adolescent family life satisfaction in remarried family households. Journal of Family Issues, 16(6), 765-786.

Izard, C. E. (1991). The psychology of emotions. Springer Science \& Business Media.

Jensen, E. W., James, S. A., Boyce, W. T., \& Hartnett, S. A. (1983). The family routines inventory: Development and validation. Social Science \& Medicine, 17(4), 201-211.

Kállay, É., \& Rus, C. (2014). Psychometric properties of the 44-item version of Ryff's Psychological Well-Being Scale. European Journal of Psychological Assessment.

Keltner, B. (1990). Family characteristics of preschool social competence among Black children in a Head Start program. Child Psychiatry and Human Development, 21(2), 95-108.

Keltner, B. R. (1992). Family influences on child health status. Pediatric nursing, 18(2), 128- 131.

Kitsaras, G., Goodwin, M., Allan, J., Kelly, M. P., \& Pretty, I. A. (2018). Bedtime routines child wellbeing \& development. BMC public health, 18(1), 386.

Kubovy, M. (1999). On the pleasures of the mind. Wellbeing: The foundations of hedonic psychology, 1999, 134-154.

La Guardia, J. G., Ryan, R. M., Couchman, C. E., \& Deci, E. L. (2000). Within-person variation in security of attachment: a self-determination theory perspective on attachment, need fulfillment, and well-being. Journal of personality and social psychology, 79(3), 367.

Laird, J., \& Hartman, A. (1988). Women, rituals, and family therapy. Journal of Psychotherapy \& The Family, 3(4), 157-173.

Malaquias, S., Crespo, C., \& Francisco, R. (2015). How do adolescents benefit from family rituals? Links to social connectedness, depression and anxiety. Journal of child and Family Studies, 24(10), 3009-3017. 
Manczak, E. M., Williams, D., \& Chen, E. (2017). The role of family routines in the intergenerational transmission of depressive symptoms between parents and their adolescent children. Journal of abnormal child psychology, 45(4), 643-656.

Martini, M. (1996). 'What's New?'at the dinner table: Family dynamics during mealtimes in two cultural groups in Hawaii. Early Development and Parenting: An International Journal of Research and Practice, 5(1), 23-34.

Myerhoff, S. F. M. B. G. (1977). Secular ritual. Uitgeverij Van Gorcum.

Myers, D. C. (1999). 19 close relationships and quality of life. Well-being: Foundations of hedonic psychology, 374.

Nezlek, J. B. (2000). The motivational and cognitive dynamics of day-to-day social life. The social mind: Cognitive and motivational aspects of interpersonal behavior, 92-111.

Palazzoli, M. S., Boscolo, L., Cecchin, G. F., \& Prata, G. (1977). Family rituals a powerful tool in family therapy. Family Process, 16(4), 445-453.

Portes, P. R., Howell, S. C., Brown, J. H., Eichenberger, S., \& Mas, C. A. (1992). Family functions and children's postdivorce adjustment. American Journal of Orthopsychiatry, 62(4), 613-617.

Reiss, D. (1981). The family's construction of reality. Harvard University Press.

Ryan, R. M., \& Deci, E. L. (2001). On happiness and human potentials: A review of research on hedonic and eudaimonic well-being. Annual review of psychology, 52(1), 141-166.

Ryff, C. D. (1989a). Beyond Ponce de Leon and life satisfaction: New directions in quest of successful ageing. International journal of behavioral development, 12(1), 35-55.

Ryff, C. D. (1989b). Happiness is everything, or is it? Explorations on the meaning of psychological well-being. Journal of personality and social psychology, 57(6), 1069.

Ryff, C. D. (1995). Psychological well-being in adult life. Current directions in psychological science, 4(4), 99-104.

Ryff, C. D., \& Keyes, C. L. M. (1995). The structure of psychological well-being revisited. Journal of personality and social psychology, 69(4), 719.

Santos, S., Crespo, C., Silva, N., \& Canavarro, M. C. (2012). Quality of life and adjustment in youths with asthma: The contributions of family rituals and the family environment. Family Process, 51(4), 557-569.

Schlebusch, L., Samuels, A. E., \& Dada, S. (2016). South African families raising children with autism spectrum disorders: relationship between family routines, cognitive appraisal and family quality of life. Journal of Intellectual Disability Research, 60(5), 412-423.
Schuck, L. A., \& Bucy, J. E. (1997). Family rituals: Implications for early intervention. Topics in early childhood special education, 17(4), 477-493.

Seymour, F. W., Brock, P., During, M., \& Poole, G. (1989). Reducing sleep disruptions in young children: evaluation of therapist-guided and written information approaches: a brief report. Journal of Child Psychology and Psychiatry, 30(6), 913-918.

Sprecher, S., \& Sedikides, C. (1993). Gender differences in perceptions of emotionality: The case of close heterosexual relationships. Sex Roles, 28(9-10), 511-530.

Springer, K. W., \& Hauser, R. M. (2006). An assessment of the construct validity of Ryff's scales of psychological well-being: Method, mode, and measurement effects. Social science research, 35(4), 1080-1102.

Sprunger, L. W., Boyce, W. T., \& Gaines, J. A. (1985). Family-infant congruence: Routines and rhythmicity in family adaptations to a young infant. Child Development, 564-572.

Turner, V. (1969). Liminality and communitas. The ritual process: Structure and anti-structure, 94, 130.

Turner, V., Abrahams, R. D., \& Harris, A. (2017). The ritual process: Structure and anti- structure. Routledge.

Viere, G. M. (2001). Examining family rituals. The family journal, 9(3), 285-288.

Waterman, A. S. (1990). Personal expressiveness: Philosophical and psychological foundations. The Journal of Mind and Behavior, 47-73.

Waterman, A. S. (1990). The relevance of Aristotle's conception of eudaimonia for the psychological study of happiness. Theoretical \& Philosophical Psychology, 10(1), 39.

Waterman, A. S. (1993). Two conceptions of happiness: Contrasts of personal expressiveness (eudaimonia) and hedonic enjoyment. Journal of personality and social psychology, 64(4), 678.

Wolin, S. J., \& Bennett, L. A. (1984). Family rituals. Family process, 23(3), 401-420.

Wolin, S. J., Bennett, L. A., \& Noonan, D. L. (1979). Family rituals and the recurrence of alcoholism over generations. The American Journal of Psychiatry.

Wolin, S. J., Bennett, L. A., Noonan, D. L., \& Teitelbaum, M. A. (1980). Disrupted family rituals; a factor in the intergenerational transmission of alcoholism. Journal of Studies on Alcohol, 41(3), 199-214.

Yoon, Y., Newkirk, K., \& Perry-Jenkins, M. (2015). Parenting stress, dinnertime rituals, and child well-being in working-class families. Family Relations, 64(1), 93-107. 